\title{
TENSION BETWEEN LEADERSHIP ARCHETYPES: SYSTEMATIC REVIEW TO INFORM CONSTRUCTION RESEARCH AND PRACTICE
}

\author{
Peter Graham ${ }^{1}$, Dr Natalia Nikolova $(\mathrm{PhD})^{2}$, Professor Shankar Sankaran $(\mathrm{PhD})^{3}$ \\ ${ }^{1}$ PhD Candidate, University of Technology Sydney Business School, PO Box 123 Broadway NSW 2007, Australia, peter.graham@uts.edu.au \\ 2 Senior Lecturer, University of Technology Sydney Business School, PO Box 123 Broadway NSW 2007, Australia, natalia.nikolova@uts.edu.au \\ ${ }^{3}$ Professor, University of Technology Sydney School of the Built Environment, PO Box 123 Broadway NSW 2007, Australia, \\ shankar.sankaran@uts.edu.au
}

\section{Manuscript accepted version}

Paper published in the Journal of Management in Engineering

Volume 36 Issue 1 - January 2020

doi: 10.1061/(ASCE)ME.1943-5479.0000722

\section{https://doi.org/10.1061/(ASCE)ME.1943-5479.0000722}

\section{ABSTRACT}

In the literature on construction projects, the role of project managers in maintaining control over tasks and activities has been theorised comprehensively, placing a firm focus on vertical forms of leadership. Increasingly, construction firms are challenged with unprecedented operational uncertainty, brought about by changes to project environments, technology and labour. Similar challenges in other contexts have led to growing research on shared or horizontal approaches to leadership, which have been particularly effective in making organisations more agile in uncertain environments. Through a systematic review of 289 peerreviewed articles on leadership in construction, this paper considers the extent to which traditional vertical approaches to leadership are supplemented with horizontal and emerging balanced approaches to leadership across six bodies of construction leadership research. It contends that despite evidence for the increasing implementation of horizontal leadership practices on construction projects, vertical leadership theory dominates construction leadership research. In comparison, there is a dearth of research addressing horizontal leadership and 
32 scarce consideration of balanced leadership. Based on the review, stronger integration of the

33 balanced leadership archetype in research on leadership in construction is proposed as a logical

34 means of advancing leadership theory in relation to six research vectors.

35

36 KEYWORDS

37 Construction projects, project management, vertical leadership, horizontal leadership,

38 balanced leadership, literature review

39 


\section{INTRODUCTION}

Few other fields in organisation studies have been explored as extensively as leadership. As Northouse (2015) observes, 'leadership is a topic with universal appeal', and one that, according to Wheatley (2010), 'has intrigued us since people began organising'. Defined broadly as an 'influence process', leadership is a pervasive phenomenon that cuts to the core of both how groups operate moment-to-moment and how they survive long-term (Denis et al. 2012). By exploring how different approaches to leadership drive or constrain success, researchers have been able to promote more informed research agendas that align emerging industry needs with theory and practice.

Research on leadership in construction projects has largely mirrored major evolutions in the broader discourse on leadership (Allport 1937; Bass 1991; Carlyle 1840; Fiedler 1964; Skinner 1938). Leaders have long been regarded as a key driver of performance and are considered integral to the effective delivery of projects (Quang et al. 2015). In particular, research has focussed on the roles of key individuals such as senior executives (Biggs et al. 2013; Gu and London 2010; Toor 2011), project managers (Larsson et al. 2015; Potter et al. 2018; Tabassi et al. 2016) and foremen (Jeschke et al. 2017; Kines et al. 2010; Mitropoulos and Cupido 2009) in fulfilling a broad spectrum of functions from stakeholder engagement to on-site safety reporting in construction projects. The hierarchic decision-making control of these individuals is seen as key to delivering high quality outcomes on budget and within schedule (Larsson et al. 2015; Love et al. 2016). By establishing a clear chain of command, leaders can maintain influence over all aspects of project delivery from supply chains (Guo et al. 2017) to risk management (Karakhan and Gambatese 2017). Through a clear line of leadership, information can reach relevant decision makers up and down the line rapidly (Dubey et al. 2015). Further, the ability of these leaders to use this information to develop grander visions of how their organizations will operate more innovatively, sustainably and 
ethically is seen as a long-term competitive differentiator (Chang et al. 2016; Simmons et al. 2017; Zhang et al. 2017).

With a large and rapidly growing body of leadership research, a number of perspectives have been put forward as to what the ideal leadership traits, behaviours and styles for leaders in construction are (Simmons et al. 2017). For example, Chan et al. (2014) identify transformational leadership as a desirable driver of innovation in construction leaders, noting that 'with charismatic, inspirational, intellectually stimulating, and individualized consideration leadership, a transformational leader motivates followers to achieve higher levels of performance by nurturing their personal value systems and facilitating their creative ways of thinking'. Alternately, Liu and Chan (2017) put forward contingent reward leadership as a desirable leadership style for stimulating innovation in construction, noting that 'contingent reward leadership influences innovation through inducing compliance'. Similarly contrasting perspectives can be found across every domain of construction leadership research. However, overwhelmingly existing research characterizes the fundamental nature of leadership in construction as a vertical influence process in which individuals enact leadership hierarchically over followers (Simmons et al. 2017).

\section{Emerging challenges to construction leadership}

The construction industry is undergoing significant changes that bring into question the effectiveness of this traditional vertical approach. Chief among these is the increasing social and technical complexity of projects (Yan et al. 2019).

Socially, construction projects are becoming more complex in both how firms engage and manage their workforces (Ball 2014; Pesämaa et al. 2018) and how they engage externally with clients and community stakeholders (Adapa 2018; Xavier et al. 2017). As Pesämaa et al. (2018) highlight, while traditionally construction firms have applied a routine set of processes 
for coordinating projects, increasingly projects 'involve multiple temporary teams of actors adapting to diverse demands and on-site conditions' requiring new approaches to coordination centred on organizational learning and collaboration. Emerging research indicates that organizational learning and collaboration stem primarily from the horizontal diffusion of information between peers (Perra et al. 2017). With increasing environmental complexity, construction firms also face similar challenges when it comes to their external engagement with clients, regulators, partners and community stakeholders (Adapa 2018). It has been suggested that traditional vertical leadership practices are not well suited to complex and dynamic environments where firms primarily require collaboration and agility. As Xavier et al. (2017) argue, the sharing of leadership responsibility amongst teams is important if construction firms are 'to deal with the complexity of environmental issues; to integrate seemingly contradictory outlooks; to understand and address the expectations of a wide range of actors and to profoundly change organizational practices'.

From a technical perspective, the way construction projects are being delivered is also rapidly changing, leading to an overall more complex delivery ecosystem for leaders to navigate (Lines et al. 2017). With planning and delivery frameworks such as building information modelling (BIM) (Wu and Issa 2014) and integrated project delivery (IPD) (Esther Paik et al. 2017) burgeoning, the managerial competencies expected of construction leaders are expanding. Simultaneously, industry shifting innovations such as big data and site automation have put a wealth of information at the fingertips of leaders with the potential to both empower and cripple decision making (Bilal et al. 2016). As Bilal et al. (2016) describe, 'facilities utilise advanced automation and integration to measure, monitor, control, and optimise building operations and maintenance. They provide adaptive, real-time control over an ever-expanding array of building activities in response to a wide range of internal and external data streams'. To an extent, these shifts have emerged in response to the tightening requirements of leading 
sustainability accreditation frameworks such as Leadership in Energy and Environmental

Design (LEED) (Abdallah and El-Rayes 2016) and Building Research Establishment

Environmental Assessment Method (BREEAM) (Tabassi et al. 2016) that add another layer of critical thinking to the role of project leaders. Recent research is indicating that seamlessly integrating these complex computerized and human systems is beyond the competencies of most leaders and requires a degree of organic collaboration between teams beyond that currently observed in the industry (Iorio and Taylor 2015). Indeed, in the case of IPD, the sharing of leadership authority is considered absolutely neccesary for a constellation of firms, partners and stakeholders to engage concertively (Esther Paik et al. 2017).

\section{Exploring new possibilities for construction leadership}

As the construction industry forges its path into this increasingly innovative, integrated and complex world, it is important it is equipped with leadership frameworks that accurately reflect the diverse array of leadership practices implemented. In light of the above challenges, this may require revision of the dominance of vertical leadership perspectives that have underpinned research on leadership in construction until now. As Tabassi et al. (2014) note, 'the nature of the industry, changing requirements of construction works and the complexity of most of the processes in a construction organization places them beyond the control of any one individual'.

However, construction leadership research has significantly lagged behind broader leadership research in theorizing the value and impact of different forms of leadership on projects' processes and outcomes. In leadership research, the recognition that vertical leadership requires rethinking can be traced back as far as the 1950s and has led to the development of a horizontal leadership archetype in which leadership influence is mobilised collectively and non-hierarchically (Denis et al. 2012; Gibb 1954). In this rich body of 
literature, horizontal leadership can take many forms, including 'emergent leadership' (Beck 1981), 'collaborative leadership' (Rosenthal 1998), 'co-leadership' (Heenan and Bennis 1999), 'collective leadership' (Denis et al. 2001), 'distributed leadership' (Gronn 2002), 'shared leadership' (Pearce and Conger 2002) and 'lateral leadership' (Day et al. 2004). While there are nuanced differences between these perspectives, they all fundamentally feature a departure from the vertical leader-follower binary that has dominated leadership research (Bolden 2011). Overall, proponents of these approaches argue that horizontal leadership is well suited to complex and dynamic environments as it has been found to facilitate organisational agility and innovativeness more effectively than vertical leadership (Cavaleri and Reed 2008; Pearce and Sims 2002; Toegel and Jonsen 2016). For example, Kaviani et al. (2017) study horizontal leadership in relation to Six Sigma teams working on healthcare projects. Centrally, they contest that horizontal leadership should be implemented in contexts with a high degree of environmental complexity where ongoing change management is required as it improves the ability of teams to communicate, adapt and innovate. Likewise, Galli et al. (2017) design an experimental approach for identifying antecedents to horizontal leadership in engineering design teams. They argue that as organizations rally in response to volatile industry demands, horizontal leadership should be implemented as it creates 'an atmosphere that consists of high levels of involvement, cooperation, shared understandings about team goals and purpose, and a sense of recognition'. Additionally, horizontal leadership has been demonstrated to be effective in situations where agile project management methods are employed, particular in software development (Bäcklander 2018; Dybå et al. 2014; Li et al. 2018; Moe et al. 2015; Moe et al. 2019; Xu and Shen 2018). For instance, Li et al. (2018) consider integrated software development teams employing agile project management practices and highlight how 'shared leadership provides the opportunity for team members to utilize their expertise and identify the best solution for a problem'. Given the growing presence of agile approaches in construction 
projects, it is important to consider whether the benefits demonstrated by horizontal leadership in other agile contexts are translatable (Mendez 2018; Saini et al. 2018). While it is likely that even in agile construction projects a degree of vertical leadership will continue to be required (De Marco 2018), overall, horizontal leadership literature demonstrates a wide range of benefits offered by the archetype for projects facing complex and dynamic environments increasingly found in construction (Denis et al. 2012).

Research on leadership in projects has so far said little about how vertical and horizontal leadership practices interact and what the impact of this interaction is on projects (Müller et al 2018a). A small number of researchers have started examining how horizontal leadership approaches are implemented in construction and have found that reconciling a project manager's formal leadership authority with informal leadership emerging amongst project teams can bring complex organisational tensions to the fore (Chan et al. 2014). Conflicting views on how different work teams should coordinate their work on-site may arise, inhibiting efficient interaction between experts (Lindgren and Packendorff 2011). In practice these tensions can prove detrimental to large projects, inciting relational strain, project lag, misguided outputs and resource overruns (Abdul Rahman et al. 2013; Doloi 2012; Larsson et al. 2015). This makes the need to investigate the interaction of vertical and horizontal leadership in construction evident. However, currently, construction lacks a mature agenda for researching and implementing the combination of vertical and horizontal leadership approaches (Simmons et al. 2017). Across other industries the same tension between vertical and horizontal leadership has prompted calls for a new approach to leadership based in 'patterns of practice which fuse or coalesce hierarchical and heterarchical elements of emergent activities' (Harris and Gronn 2008). In response, researchers have recently proposed a third, balanced leadership archetype, that aims to simultaneously leverage both vertical and horizontal leadership through practices which manage the tensions resulting from the 
combination of multiple leadership approaches (Drouin et al. 2018; Müller et al. 2018a; Pretorius et al. 2017; Yu et al. 2018).

According to the balanced leadership approach, project managers serve as a central conduit between a pool of strategic leaders and the project team, facilitating agile decision making between senior and team-level leadership (Müller et al. 2018b). The approach sees teams progress independently through a sequence of phases where empowerment, selfmanagement and shared mental models are used to create shared socio-cognitive space; a common mental space between teams and project managers which supports interaction between vertical and horizontal leaders (Müller et al. 2018a; Yu et al. 2018). This shared sociocognitive space has been found to enable six key practices that encourage effective interaction between vertical and horizontal leaders: enabling consensus building, developing team competence, fostering knowledge transfer, defining a control layer, building strategic agility and enabling localized autonomy (Drouin et al. 2018; Müller et al. 2016; Yu et al. 2018). While research on balanced leadership is in its infancy with only a handful of researchers studying its applications, early findings indicate it offers a valuable lens for conceptualising and managing the integration of vertical and horizontal leadership in project-based organizations operating in complex environments (Drouin et al. 2018).

\section{Towards a three-archetype leadership paradigm in construction}

Given the potential positive impact of horizontal and balanced leadership approaches on construction projects, it is important to review how the different leadership archetypes have been discussed in construction research so far and consider their implications for future research. To achieve this, construction leadership research must be synthesized to understand first, what the key concerns of the field are, and second, how vertical, horizontal and balanced leadership have been discussed in relation to each of these concerns. In order to categorize the 
literature against these three leadership approaches a classification scheme has been developed

216 (see Table 1 below). The classification scheme considers how the archetypes differ across three

217 key ontological dimensions of leadership as described in the integrative ontology of Drath et

218 al. (2008). First, the scheme considers how leadership is described in each archetype. Flowing

219 from this, the scheme then considers how leadership manifests according to each archetype.

220 Third, the scheme considers the level/s of leadership influence once it has manifested. Finally,

221 to aid in categorization, the scheme also sets adjectives commonly used throughout the

222 literature to describe vertical, horizontal and balanced leadership.

Table 1. Leadership archetype classification criteria

\begin{tabular}{|c|c|c|c|}
\hline $\begin{array}{l}\text { Ontological } \\
\text { dimension }\end{array}$ & Vertical leadership & Horizontal leadership & Balanced leadership \\
\hline $\begin{array}{l}\text { Leadership is } \\
\text { described as }\end{array}$ & $\begin{array}{l}\text { A process of influence between a leader and } \\
\text { followers (Hollander 1992) } \\
\text { The behaviour an individual adopts when he is } \\
\text { directing a group towards a goal (Hemphill and } \\
\text { Coons 1957) } \\
\text { A person who attempts to influence other people } \\
\text { towards a certain outcome (Korman 1971) } \\
\text { A process of social influence in which an } \\
\text { individual guides a group towards a goal (Bryman } \\
\text { 2013) }\end{array}$ & $\begin{array}{l}\text { An emergent processes of social interaction (Davis } \\
\text { and Eisenhardt 2011) } \\
\text { A collective group property (Paunova 2015) } \\
\text { A group activity enacted through relationships and } \\
\text { not individual action (Bennett and Anderson 2003) } \\
\text { A collection of people operating in multiple } \\
\text { influential and interdependent roles (Pearce and } \\
\text { Conger 2002) }\end{array}$ & $\begin{array}{l}\text { Individual and group/shared interaction guided by } \\
\text { structures, processed and shared frameworks that } \\
\text { create a shared social-cognitive space (Müller et al. } \\
\text { 2016) } \\
\text { An iterative approach involving five events, each } \\
\text { outlining specific roles for vertical and horizontal } \\
\text { leaders. The five events are: nomination, } \\
\text { identification, selection, horizontal leadership and its } \\
\text { governance, and transition (Müller et al. 2018) }\end{array}$ \\
\hline $\begin{array}{l}\text { Leadership } \\
\text { manifests through }\end{array}$ & $\begin{array}{l}\text { Great individuals (Carlyle 1840) } \\
\text { Individuals who naturally possess a particular set } \\
\text { of traits (Allport 1937) } \\
\text { Individuals who exhibit particular behaviours } \\
\text { (Skinner 1938) } \\
\text { Individuals who are able to adapt their leadership } \\
\text { to suit the circumstances at hand (Fiedler 1964) } \\
\text { Individuals who can offer followers extrinsic } \\
\text { rewards for achieving goals (Bass 1991) } \\
\text { Individuals who can create transformation by } \\
\text { motivating followers towards a common vision } \\
\text { (Bass and Riggio 2006) } \\
\text { Individuals who exemplify positive behaviour and } \\
\text { build authentic relationships with followers (Toor } \\
\text { and Ofori 2008) }\end{array}$ & $\begin{array}{l}\text { Interaction between many individuals (Davis and } \\
\text { Eisenhardt 2011) } \\
\text { Diads, triads and constellations of leaders (Denis } \\
\text { et al. 2001) } \\
\text { Networks of mutually dependent individuals } \\
\text { (Carson et al. 2007) } \\
\text { Subconscious relays of influence over time } \\
\text { (Spillane et al. 2007) } \\
\text { Distributed functions that architect the culture of } \\
\text { an organization (Schein 2010) } \\
\text { The social architecture of an organization (Bolman } \\
\text { and Deal 2017) }\end{array}$ & $\begin{array}{l}\text { Vertical and horizontal leaders interacting during } \\
\text { five events (Müller et al. 2016) } \\
\text { Teams and key individuals who span boundaries } \\
\text { between teams (Müller et al. 2018) }\end{array}$ \\
\hline $\begin{array}{l}\text { Leadership influence } \\
\text { moves between }\end{array}$ & $\begin{array}{l}\text { Individuals on different levels of a hierarchy } \\
\text { (Ramthun and Matkin 2012) }\end{array}$ & $\begin{array}{l}\text { Individuals on the same level of a hierarchy or } \\
\text { between individuals cooperating without hierarchy } \\
\text { (Denis et al. 2012) }\end{array}$ & $\begin{array}{l}\text { Groups of individuals on the same levels of a } \\
\text { hierarchy and between groups on different levels of } \\
\text { the hierarchy (Müller et al. 2018) }\end{array}$ \\
\hline $\begin{array}{l}\text { Common adjectives } \\
\text { include }\end{array}$ & $\begin{array}{l}\text { Vertical, transactional, transformational, visionary, } \\
\text { authentic, consultative, authoritarian, executive, } \\
\text { individual, structured, directive, person-centred, } \\
\text { autocratic, hierarchic }\end{array}$ & $\begin{array}{l}\text { Horizontal, shared, collective, distributed, } \\
\text { collaborative, dispersed, diffuse, lateral, non- } \\
\text { hierarchic, emergent, organic, interactionist, team- } \\
\text { centred, non-binary }\end{array}$ & $\begin{array}{l}\text { Balanced, integrated, hybrid, socio-cognitive, mixed, } \\
\text { multi-level, iterative, situational, recurring, } \\
\text { generative, cyclic }\end{array}$ \\
\hline
\end{tabular}


vertical, horizontal and balanced leadership according to the classification criteria set out above, gaps in construction leadership theory can be identified and compiled into a robust research agenda. Such a research agenda can guide future research on leadership in construction towards extending existing frameworks and models to better align leadership research with different contexts and changing requirements of work. In addition, with this agenda, further research can support practitioners in facing emerging challenges, such as increasing pressure for programmatic engagement of stakeholders (Adapa 2018; Yan et al. 2019) or the need to rapidly share cutting-edge technical knowledge across teams (Ni et al. 2018; Zhang et al. 2018c). This could help practitioners better address the ever-increasing social and technical complexity of leading construction projects.

With this research objective in mind, this review will first set out its three-stage systematic review methodology. Next, results from the bibliometric analysis will be presented, identifying key clusters of leadership research in construction, before these clusters will be synthesized into a robust research agenda. Finally, the implications of this research agenda for construction leadership theory and practice will be discussed before limitations of the study are flagged and directions for future research highlighted.

\section{METHODOLOGY}

To offer as thorough, objective and meaningful a review of construction leadership literature as possible, this paper adheres to a three-stage systematic review methodology (Randhawa et al. 2016). Overall, the systematic review synthesizes a wide body of high quality peer-reviewed articles in order to offer a rigorous assessment of theoretical connections that can inform deeper critical reflection on existing research in a field (Randhawa et al. 2016). The theoretical underpinnings of the approach are widely recognized in the literature (Booth et al. 2016; Brereton et al. 2007; Kitchenham et al. 2009; Pawson et al. 2005). The methodology is 
designed to minimize researcher influence on findings by setting out agreed standards for establishing the relevance, plausibility and credibility of research claims (Pawson et al. 2005). It prioritizes the implementation of a transparent process for sample selection and analysis over the overall breadth of a sample (Booth et al. 2016). Lastly, the systematic review methodology involves computerized techniques for bibliometric analysis (Perianes-Rodriguez et al. 2016), the development of clear criteria to inform thematic analysis (Brereton et al. 2007), and comparison of analyses between multiple authors (Booth et al. 2016).

In the current review, literature is first collected according to sampling criteria which set boundary conditions on the study while ensuring the relevance and quality of the sample (Booth et al. 2016). Second, the entire sample undergoes bibliographic-coupling analysis to identify key bodies of theory in relation to leadership in construction (Boyack and Klavans 2010). Finally, aggregative thematic analysis is used to draw out salient themes from key citations in each body of research and synthesize key questions for future construction leadership research. Through this comparison key touchpoints between leadership archetypes and construction leadership theory are identified and the value of integrating the bodies of research is assessed.

\section{Literature sampling}

Sample literature for this review was collected via a four-stage sampling process. First, Scopus was used to search for an initial sample. Scopus is the largest abstract and citation database of peer-reviewed literature available representing between 18,000 and 22,000 journals (Aghaei Chadegani et al. 2013). This was done by conducting searches for journal articles published in English since 1997 in the field of construction which contained either 'leadership', 'leader' or 'leading' in either their title or keywords. This search returned a total of 375 articles. To ensure the sample remained relevant to the objective of this review, the results of this search 
were then restricted using Scopus subject area fields to articles stemming from a business, management, decision sciences or sociological framing. This ensured a number of results discussing leadership in the context of technical advances in software, biomedical, industrial, chemical and materials sciences were excluded from the results. Further, to ensure sample literature was of reasonable quality, only journals with a $\mathrm{H}$-index of 5 or greater were included. Finally, the abstracts of all articles were reviewed separately by all three authors according to exclusion criteria to ensure articles in the sample were relevant (Randhawa et al. 2016). The exclusion criteria required any articles which did not explicitly concern construction or did not have leadership as their analytic focus be removed from the sample. Examples of removed papers include: papers focussed on military leadership (Abrahms and Mierau 2017; Cohen and Scheinmann 2014; Keller and Matusitz 2015), political leadership (Chedia 2014; Cohen and Scheinmann 2014; Woltjer 2015), and papers that only mentioned leadership in passing (Annan et al. 2015; Bruyelle et al. 2014; Holly et al. 2017) or in the context of industry leadership on an institutional level (Morrison and Rabellotti 2017; Niskanen et al. 2014; Wang and Liu 2012). This sampling process can be seen below in Figure 1 and resulted in the removal of 85 results leaving a final sample of 289 articles from 79 journals. The final list of sample literature can be seen in Table 2 below.

(1)

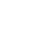

(1)

(1)

(1)

1

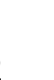

3

4




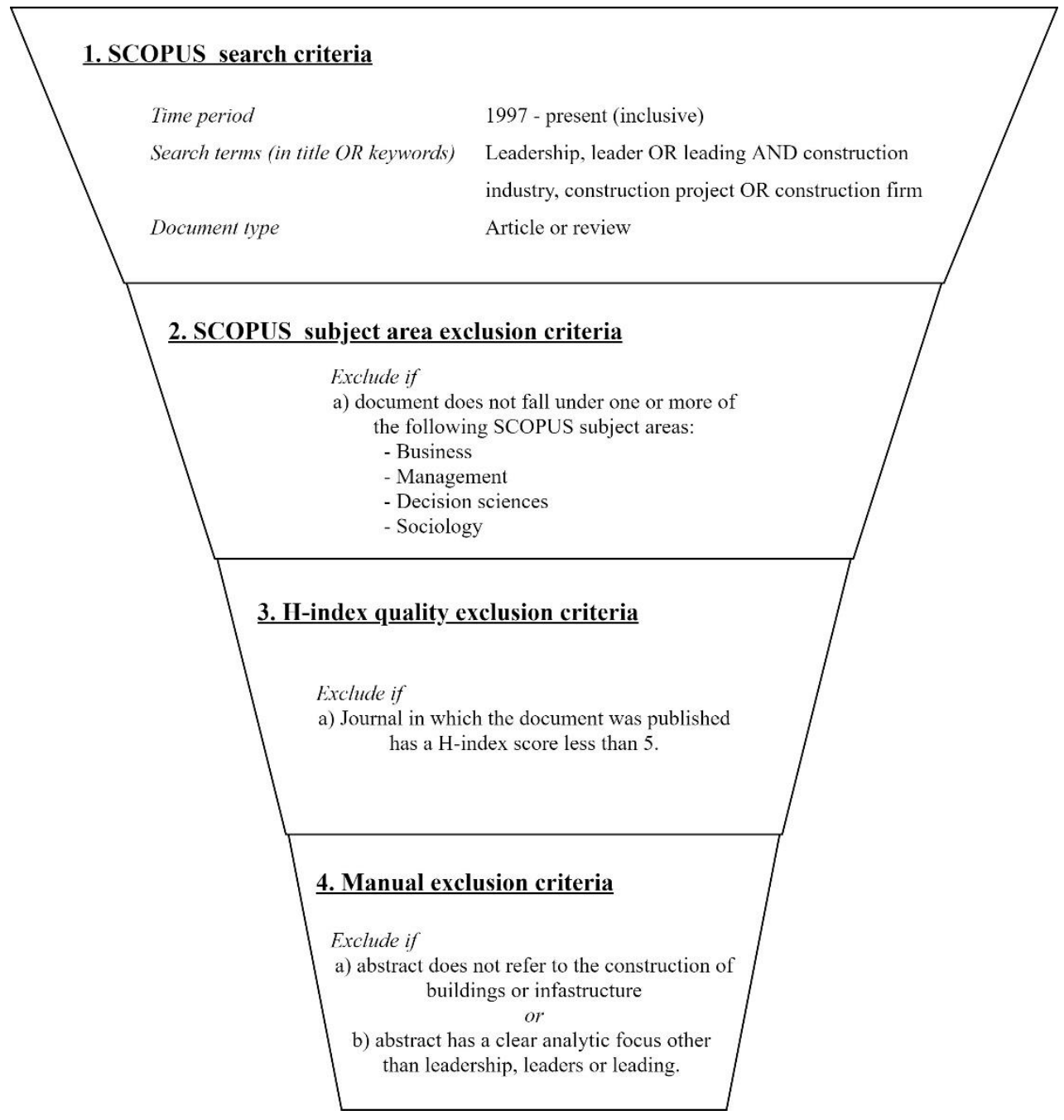

320

Table 2. Consolidated sample literature

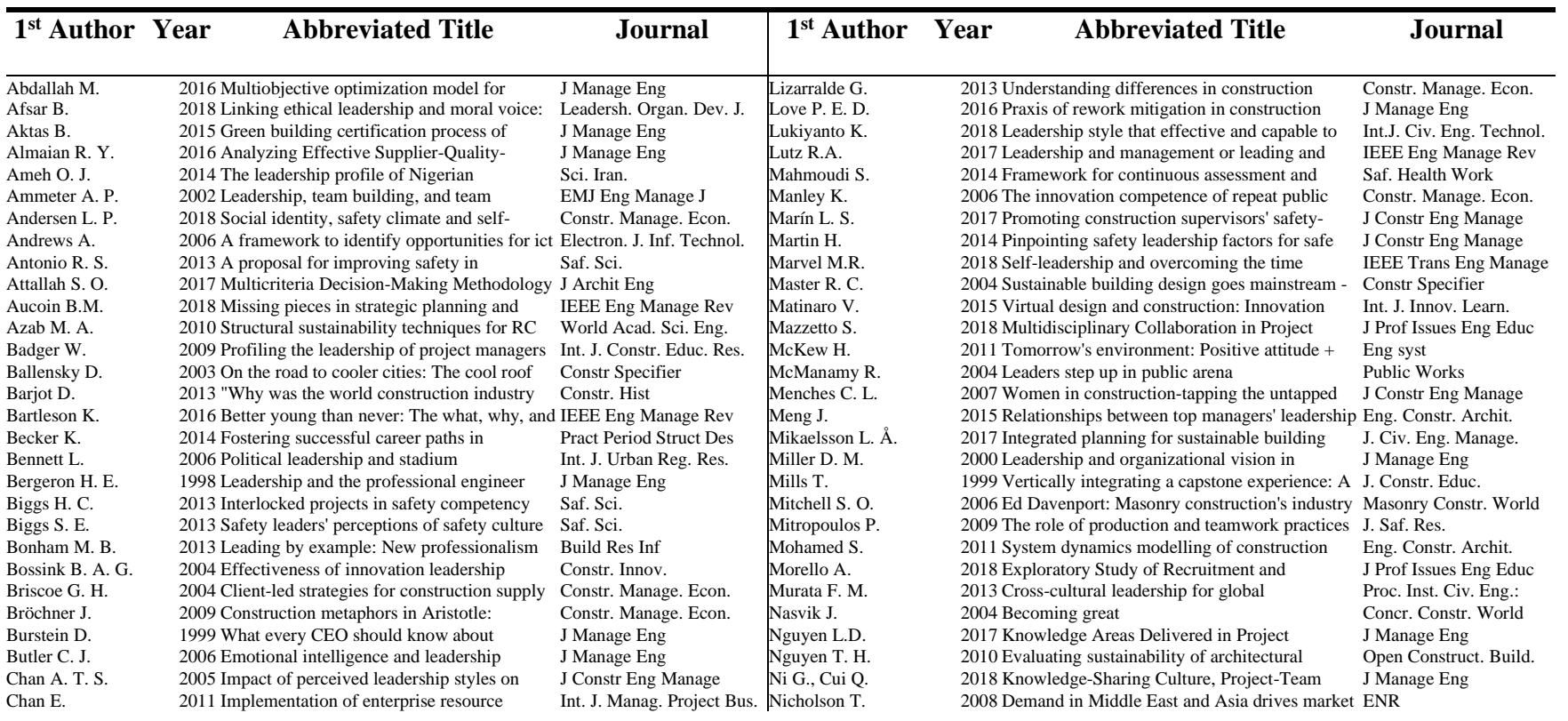


Chan E.

Chan I. Y. S.

Chang Y. F.

Cheng E. W. L.

Cheung S. O.

Chiang Y. H

Chih Y. Y.

Chinowsky P.

Chiu C.-H.

Choi S.

Chowdhury T.

Clauson D.

Clauson D.

Cross S.

Cross S.E.

Cross S.E.

Custovic E.

Da Silva L.

Dainty A. R. J.

Dall'O G.

Daniel L.

Davidson K.

Dawood N.

Del Vecchio J. A.

Delaney T.

DeVilbiss C. E.

Dewlaney K. S.

Dewlaney K.

Dey S. S.

Dingsdag D. P.

Dixon C.

Doan D. T.

Dossick C. S.

El-Adaway I. H.

El-Gohary K. M.

Ellis L. A.

Elzarka H. M.

Enshassi A.

Esther Paik

Evans M.

Farr J. V.

Fellows R.

Filos E.

Fiolet J. C.

Fortunato Iii B. R.

Gabriel E.

Galli B. .

Galli B.J.

Gaynor G.

Gharehbaghi K.

Giraldo D.

Giritli $\mathrm{H}$.

Giritli $\mathrm{H}$.

Godfrey Ochieng

Gonchar J.

Grill M.

Grisham T.

Gu N.

Gunawansa A.

Gushgari S. K.

Hallowell M. R.

Hart S. D.

Hay M. A.

Hellmund A. J.

Hensey M.

Ho P. H. K.

Hoffmeister K.

Holt R.

Hu Y.

Hu Y

Huff W.

Huff W.

Ibrahim C. K.

Ibrahim C. K.
Idoro G. I.

Ites A.

Janzen A.

Jeschke K. C.

Jiang W

Jitwasinkul B.

Judy S.

Kaman V. S.

Kapp E. A.

Karakhan A. A.

Karakhan A. A.

Karallis T.

Kasapoğlu E.

Kasapoğlu E.

Kerdngern $\mathrm{N}$.

Khullar Relph M.

Kines P.

Kissi J.

Klemens T.
2008 Impact of leadership and power on

Int. J. Hum. Resour. Dev. Odusami K. T.

列

2016 Understanding innovations in Malaysia's

2015 Use of safety management practices for

Asian J. Technol. Innov.

Int. J. Injury Cont. Saf.

2015 A non-linear case-based reasoning approach Build. Environ.

2001 A satisfying leadership behaviour model for Int. J. Proj. Manage.

2008 Volume building as competitive strategy Constr. Manage. Econ.

2017 Feeling Positive and Productive: Role of

J Constr Eng Manage J Manage Eng

2016 Coordinating Supply Chains with a General IEEE Trans Eng Manage

$\begin{array}{ll}2017 \text { Construction Workers' Group Norms and } & \text { J Manage Eng } \\ 2009 \text { Correlation between innovation and } & \text { Can. J. Civ. Eng. }\end{array}$

2009 Correlation between innovation and

3 Impact of senior design project for the

2018 Lead yourself

2018 Build your own leadership model

2018 What Kind of Leader Do You Want to Be?

2016 From engineer to manager, mastering the

2009 Review of the LEED points obtained by

2005 Competency-based model for predicting

2013 On the integration of leadership in energy

2015 Safety leadership defined within the

2013 Tocci Building Cos. grows into national

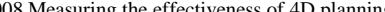

. Inf. Technol.

J Manage Eng

(

2012 Prevention through design and construction Constr. Manage. Econ.

2012 Safety risk quantification for high

$\begin{array}{ll}2015 \text { Public agency performance management for J Manage Eng } \\ 2008 \text { Understanding and defining OH\&S } & \text { Saf. Sci. }\end{array}$

$\mathrm{Saf}$. Sci.

A critical comparison of green building

2016 As brexit dust settles, european leaders and

J Constr Eng Manage

. J Manage En

2011 A way forward: Assessing the demonstrated Leadersh. Manage. Eng.

riscioning J Manage Eng

2009 Factors affecting the performance of J. Civ. Eng. Manage.

2017 Interorganizational Projects: Reexamining J Manage Eng

2008 Heathrow Terminal 5: Health and safety Proc. Inst. Civ. Eng. Civ.

016 Efrect of path

(1997 Leader

1903 Leadership development for engineering

2009 Advanced ICT under the 7th EU R\&D

2016 Risk-chasing behaviour in on-site

2012 Identification of safety risks for high-

1997 Lean approach to project management

Proc. Inst. Civ. Eng. Civ.
Int. J. Constr. Manage.

J Manage Eng

Constr. Manage. Econ.

Electron. J. Inf. Techno

Constr. Manage. Econ.

J Constr Eng Manage Int J Proj Manage

What Risks Does Lean Six Sigma Introduce? IEEE Eng Manage Rev

2017 Taking the lead and managing innovation IEEE Eng Manage Rev

1997 Leadership is essential to managing success J Manage Eng

2003 The construction manager as a leader Leadersh. Manage. Eng.

2010 Washington state's I-405 project: Women in Leadersh. Manage. En 2013 The interplay between leadership and Int. J. Proj. Manage.

2004 Leadership styles: Some evidence from the Constr. Manage. Econ.

2009 Framework for managing multicultural Eng. Constr. Archit.

2005 Rapidly evolving rating system draws:

1998 Collaborations subcommittee keynote

2017 Supervisors and teachers' influence on

2008 Temporary project cultures

ENR

J Manage Eng

Empir. Res. Vocat. Educ.

2010 Understanding and facilitating BIM adoption Autom Constr

2014 A comparison of climate change mitigation Sustainable Dev.

1997 Skills critical to long-term profitability of J Manage Eng

2013 Enterprise risk management strategies for J Manage Eng

2014 Conceptual models for infrastructure J Manage Eng

2004 Lighting Design for Sustainable Buildings Constr Specifie

2008 Facing the challenges of integrated design Energy Eng

1999 Why and how of facilitative leadership J Manage Eng

2016 Analysis of Competitive Environments, J Manage Eng

2014 The differential effects of transformational Saf. Sci.

2000 Total quality, public management and Int. J. Qual. Reliab.

2015 Understanding the determinants of program J Manage Eng

2015 From construction megaproject management J Manage Eng

2006 Specifying for water efficiency

Constr Specifier

2006 Changing approaches to health care prompt ENR

2015 Establishment of quantitative measures for J Manage Eng

2009 Clients' perception of construction project J. Eng. Des. Technol.

2006 New heights of conservation: MRL elevators Constr Specifier

2006 Innovations from brandenburg brand leader Betonwerk Fertigteil Tech

2017 Process evaluation of a Toolbox-training Saf. Sci.

2017 The impact of transformational leadership on Sustainability

2016 A Bayesian Belief Network model of Saf. Sci.

2018 Pond's culture builds a basis for success ENR

1999 Going to the future to develop transportation J Manage Eng

2012 The influence of supervisor leadership Saf. Sci.

2017 Integrating Worker Health and Safety into J Constr Eng Manage

2017 Identification, quantification, and

2009 Making mentoring stick: A case study

2011 Building better futures: Leveraging action Educ. Train.

2014 Leadership styles in architectural design J J Constr Eng Manage

2017 Influence of contemporary leadership on job Intern. J. Eng. Bus.

2014 Factors influencing unsafe behaviors and Int. J. Occup. Saf. Ergon.

2011 Green building Booms in India

EN

2012 mproving construction site safety through J. Saf. Res.

Concr. Constr. World

Odusami K. T.
Odusami K. T.

Odusami K.
Ofori G.

fori $G$

Ofori G.

Oladinrin O. T.

Opoku A.

Opoku A.

Oyewobi L. O.

Ozorhon B.

Ozorhon B.

Ozorovskaja R.

ais C. L. A.

Papajohn D.
Parkin J.

Parkin J.

Pesämaa O.

Pheng L. S.

Philips A.

irzadeh P.

Polesie P. M. A.

Post N. M.

Potter E. M.

Powers E. M.

ries F.

ryke $S$.

Rajagopalan S.

Rajendran S.

Ramakrishnan R.

Randeree K.

Rapp R. R.

Riley D. R.

Rojas E. M.

Rowlinson S.

Rozgus A.

Rubin D. K.

Rubin D. K.

Schor D.

Senaratne $S$

Senaratne $S$.

Shen W.

Shiplee $\mathrm{H}$

Shoop B.L.

Siddiqi K.

Siew R. Y. J.

immons D. R.

Singh A.

ingh A.

Singh A.

Skeepers N. C.

kipper C. O.

Skipper C. O.

Skipper C. O.

Skopek J.

lates K.

Slattery D. K.

Spatz D. M.

Styhre A.

tyhre A.

Sui Pheng L.

Sunindijo R. Y
Sunindijo R. Y

Sunindijo R. Y.

Tabassi A. A.

Tabassi A. A.

Tener R. K.

Terouhid S. A.

Tombesi P.

oor S. R.

Toor S. u. R.

Toor S. U. R.

Toor S. U. R.

Toor S. U. R.

oor S. U. R.

Toor S. U. R.

oor S. U. R.

Toor S. U. R.

Tran N.

Tuchman J. L.

uohy P. G.

Umar T.

Verstraete $\mathrm{T}$.

avelsbergh C. M. J. 


\begin{tabular}{|c|c|c|c|c|c|}
\hline Knauseder I. & 2007 Learning approaches for housing, service & Constr. Manage. Econ. & Wu C. & 2015 Roles of owners' leadership in construction & Int. J. Proj. Manage. \\
\hline Koh T. Y. & 2010 Empiricist framework for TQM & $\mathrm{J}$ Manage Eng & Wu C. & 2017 Leadership improvement and its impact on & Int. J. Proj. Manage. \\
\hline Larsson J. & 2015 Leadership in civil engineering: Effects of & J Manage Eng & Wu C. & 2016 How safety leadership works among owners, & Int. J. Proj. Manage. \\
\hline Lee T. S. & 2005 Superior-subordinate relationships in Korean & J Manage Eng & Wu W. & 2014 BIM execution planning in green building & J Manage Eng \\
\hline Leonard J. & 2004 Masonry construction's industry leader of the & Masonry Constr. World & Wu W. & 2016 Pedagogy and assessment of student learning in & J. Inf. Technol. Constr. \\
\hline Leonard M. & 2003 Leed $^{\text {TM }}$ Takes off at George C. Marshall & Constr Specifier & Xia B. & 2015 Design-build contractor selection for public & J Manage Eng \\
\hline Leotta A. & 2017 Management accounting and leadership & Qual. Res. Account. & Yan $\mathrm{H}$. & 2019 Critical Success Criteria for Programs in China: & J Manage Eng \\
\hline Li A. S. & 2016 Strategies for Foreign Construction-Related & J Manage Eng & Yang J. & 2017 Sustainability evaluation of the Great Wall of & Civ. Eng. Environ. Syst. \\
\hline Limsila K. & 2008 Performance and leadership outcome & Eng. Constr. Archit. & Yengst C. R. & 2003 Terex - From a follower to an industry leader & Diesel Progr Int Edit \\
\hline Lindebaum D. & 2011 'it's good to be angry': Enacting anger in & Hum. Relat. & Yudelson J. & 2005 Understanding the marketplace for green & Constr Specifier \\
\hline Lines B.C. & 2017 Drivers of Organizational Change within the & $\mathrm{J}$ Manage Eng & Zhang B. & 2017 Causes of Business-to-Government Corruption & J Manage Eng \\
\hline Lines B.C. & 2017 Implementing Project Delivery Process & $\mathrm{J}$ Manage Eng & Zhang $\mathrm{L}$. & 2018 The mediation role of leadership styles in & Int. J. Proj. Manage. \\
\hline Ling F. Y. Y. & 2012 Careers development in construction firms: & Eng. Constr. Archit. & Zhang L. & 2018 Perceiving interactions and dynamics of safety & Saf. Sci. \\
\hline Lingard H. C. & 2009 Group-level safety climate in the Australian & Constr. Manage. Econ. & Zhang $\mathrm{L}$. & 2016 Perceiving interactions on construction safety & J Manage Eng \\
\hline Linowes J. G. & 1998 Leadership in transition: Preparing your firm & $\mathrm{J}$ Manage Eng & Zhang Y. & 2018 How does transformational leadership promote & Sustainability \\
\hline Liu A. & 2003 The power paradigm of project leadership & Constr. Manage. Econ. & Zheng J. & 2017 Impacts of leadership on project-based & Sustainability \\
\hline Liu A. M. M. & 2017 Understanding the Interplay of & J Manage Eng & Zilke J. P. & 2015 Shifting sands and shifting grounds: Analysis & $\mathrm{J}$ Manage Eng \\
\hline Liu A. M. M. & 2006 A power-based leadership approach to & Constr. Manage. Econ. & & & \\
\hline
\end{tabular}

\section{Bibliographic coupling analysis}

In order to accurately map the research front of literature addressing leadership in

the relatedness of publications based on the number of references they share (Boyack and

Klavans 2010). This allows the identification of trends and relationships within a scientific discourse with rigour and objectivity (Gmür 2003). It has been demonstrated that of the three pure citation-based methods for mapping research fronts (co-citation analysis, bibliographic coupling of publications represented in the sample. While bibliographic coupling cannot offer precise theoretical insights regarding the state of knowledge in construction leadership, it is able to provide high-level insights into the connectedness of publications within a sample and 2010).

In the bibliographic coupling map output by VOS, citations are clustered according to Louvian grouping principles (Blondel et al. 2008). When given a set of bibliometric data, VOS will first produce a matrix in which the similarity of citations in the dataset is determined by calculation of the frequencies with which citations appear relative to one another (Van Eck and as the arrangement in which the distance between any two citations most accurately represents 
their similarity established in the matrix and the weighted sum of the squared Euclidean distances between all pairs of citations is minimized (Van Eck and Waltman 2009). Using this arrangement, VOS outputs a coloured bibliographic coupling map to graphically represent how frequently citations are cited and how they are clustered based on their similarity to other citations. Given the complexity of the network output by VOS, outlining clusters for black and white reading proved impractical and so the figure is not presented in this review. The purpose of these clusters is to indicate groups of citations with high internal affinity which may indicate the presence of a particular perspective, discipline or theoretical frame (Perianes-Rodriguez et al. 2016). It is beyond the purview of this review to explore the functions by which VOS clusters and maps citations in greater depth as this has been well established in scientometric literature (Van Eck and Waltman 2009).

Aggregative thematic analysis

Once bibliographic coupling analysis had been completed, the abstracts of all papers contained in the resulting clusters underwent aggregative thematic analysis in order to identify the overriding topics addressed by literature in each cluster (Tranfield et al. 2003). This process involved the first and second author developing an initial set of codes that provide literal descriptions of concepts contained within the paper abstracts (for instance 'informtion \& communications technology', 'total quality management' or 'rework mitigation'). Subsequently, the first and second author independently reviewed these codes to identify similar or overlapping concepts and build an aggregated set of themes that accurately depict the substantive focus of each cluster. The themes identified by the first and second author aligned closely for all clusters with the exception of cluser 2 where the themes of 'Innovation' and 'Sustainability' were both deemed to accurately depict the substantive focus of the cluster.

367 Given the frequency of articles simultaneously addressing innovation and sustainability in 
cluster 2, the first and second author agreed that the theme 'Innovation and Sustainability' suitably reflects the research in cluster 2 . Based on this thematic analysis, summaries of findings were produced for each cluster which are presented in the results.

Finally, using the categorizonation criteria set out above in Table 1, articles were read in full to identify where authors discussed vertical, horizontal and balanced leadership (Denis et al. 2012). A research agenda was then developed for each of the six clusters identified based on this categorization and key concerns highlighted by the most recent literature within the cluster. Given that it is the intention of this review to provide a clear indication of the distribution of construction leadership research across the three leadership archetypes, articles were not allowed to span archetypes where they may have alluded to multiple archetypes. Instead articles were categorized based on the leadership archetype discussed most frequently. This scenario arose only a small number of times and always involved articles focussed on vertical leadership that occasionally drew on concepts from horizontal leadership theory. For example, Zhang et al. (2018a) primarily discuss vertical leadership in relation to IPD, however, they also draw on concepts such as 'collaboration' and 'integration' to describe how vertical leadership must engage with the delivery team. The above process resulted in the research agenda found at the end of the results in Table 4.

\section{RESULTS}

Of the 289 articles subject to bibliographic coupling analysis, VOS identified that 197 articles share references with at least one other article in the sample. This indicates that 93 articles within the sample did not share references. Contained in the network of 197 connected articles are 6 clusters. These clusters represent groups of articles citing each other more frequently than articles outside of their cluster and give an indication of the boundaries between theoretical perspectives. Lists of all articles contained in the six clusters can be found in Table 3 below. 
Table 3. Article clusters ranked by citations $(C)$

\begin{tabular}{|c|c|c|c|c|c|c|c|c|c|c|c|}
\hline \multicolumn{2}{|c|}{ Cluster 1} & \multicolumn{2}{|c|}{ Cluster 2} & \multicolumn{2}{|c|}{ Cluster 3} & \multicolumn{2}{|l|}{ Cluster 4} & \multicolumn{2}{|c|}{ Cluster 5} & \multicolumn{2}{|l|}{ Cluster 6} \\
\hline Article & $\mathrm{C}$ & Article & $\mathbf{C}$ & Article & $\mathrm{C}$ & Article & $\mathbf{C}$ & Article & $\mathrm{C}$ & Article & $\mathrm{C}$ \\
\hline es (2010) & & $3 \mathrm{Gu}(2010)$ & 245 & Dainty (2005) & 79 & Briscoe (2004) & 105 & Dossick (2010) & 125 & Odusami (2003) & 53 \\
\hline lliams Jr. (2010) & & 5 Limsila (2008) & & Enshassi (2009) & 73 & Manley (2006) & 43 & Butler (2006) & 62 & Chan (2005) & 46 \\
\hline jendran (2009) & & $\mathrm{Hu}(2015 b)$ & & Odusami (2002) & & Chinowsky (2007) & 39 & Ammeter (2002) & 54 & Giritli (2004) & 37 \\
\hline Kapp (2012) & & $\mathrm{Wu}(2014)$ & & Toor (2008b) & & Devilbiss (2000) & 38 & Chan (2014) & 19 & Fellows (2003) & 33 \\
\hline ingsdag (2008) & & 5 Ozorhon (2014) & & El-Gohary (2014) & 54 & Godfrey Ochieng (2009) & 28 & Toor (2009b) & 15 & Liu (2006) & 31 \\
\hline Ioffmeister (2014) & & Wallhagen (2011) & 2. & 5 Sunindijo (2007) & 5 & Pham (2006) & 28 & Kissi (2012) & 14 & Wong (2007) & 30 \\
\hline ortunato Iii (2012) & & Bossink (2004) & 23 & Lindebaum (2011) & 50 & Dawood (2008) & 20 & Koh (2010) & 13 & Giritli (2013) & 28 \\
\hline itropoulos (2009) & & Doan (2017) & 2 & Toor (2009a) & 31 & Styhre (2011) & 20 & Lee (2005) & 13 & Ozorovskaja (2007) & 23 \\
\hline onchie (2013) & 3 & Potbhare (2009) & 20 & Menches (2007) & 28 & Pries (2004) & 17 & 7 Larsson (2015) & 12 & Liu (2003) & 20 \\
\hline ngard (2009) & 3 & Aktas (2015) & & Skipper (2006a) & 27 & 7 Chiang (2008) & 14 & Tabassi (2016) & 11 & Cheung (2001) & 19 \\
\hline $\operatorname{ggs}(2013 b)$ & & 5 Tuohy (2015) & 17 & Skipper (2006b) & 24 & Holt (2000) & 12 & Savelsbergh (2015) & 10 & Randeree (2012) & 19 \\
\hline osravi (2014) & & Cheng (2015b) & 16 & Toor (2010) & 22 & Knauseder (2007) & 12 & Zheng (2017) & 10 & Ofori (2009) & 11 \\
\hline Mahmoudi (2014) & & $\mathrm{Hu}(2015 \mathrm{a})$ & 13 & Toor (2008d) & 19 & Love (2016) & & Spatz (1999) & & Toor (2008a) & 11 \\
\hline ewlaney (2012b) & & Ibrahim (2015) & 1 & Ofori (2012) & 17 & Ofori (2015) & & Pais (2010) & & Parkin (1997) & 6 \\
\hline ewlaney (2012a) & & 7 Tombesi (2006) & 10 & Ellis (2011) & 12 & Oladinrin (2016) & & Bröchner (2009) & & Kasapoğlu (2014) & 5 \\
\hline Mohamed (2011) & & Ozorhon (2017) & & Toor $(2008 \mathrm{c})$ & 11 & Andrews (2006) & & Jiang (2017) & & Singh (2010) & 5 \\
\hline $\mathrm{Vu}(2016 \mathrm{a})$ & & $\mathrm{Xia}(2015)$ & & Skipper (2008) & & Choi (2009) & & 5 Tabassi (2014) & & Sui Pheng (1997) & 4 \\
\hline owlinson (2015) & & Bonham (2013) & & Sunindijo (2012) & & Lizarralde (2013) & & 5 Chih (2017) & & Chan (2011) & 3 \\
\hline $\mathrm{Vu}(2015)$ & & Abdallah (2016) & & Toor (2011a) & & Oyewobi (2016) & & Liu (2017) & & Ameh (2014) & 2 \\
\hline hiplee (2011) & & Dall'o' (2013) & & Antonio (2013) & & Styhre (2007) & & Zhang (2018c) & & Chan (2008) & 2 \\
\hline iggs (2013a) & & Senaratne (2015a) & & Chowdhury (2013) & & Weingardt (1997) & & $\operatorname{Rapp}(2014)$ & & Grill (2017) & 1 \\
\hline itwasinkul (2016) & & Dey (2015) & & Meng (2015) & & Almaian (2016) & & Simmons (2017) & & Grisham (2008) & 1 \\
\hline $\operatorname{artin}(2014)$ & & Idoro (2009) & & Slattery (2011) & & Ho (2016) & & Waziri (2015) & & Murata (2013) & 1 \\
\hline Karakhan (2017b) & & 5 Papajohn (2017) & & Leotta (2017) & & $\mathrm{Li}(2016)$ & & Zhang (2018a) & & Zhang (2017) & 1 \\
\hline oojas (2013) & & Wu (2016b) & & Mikaelsson (2017) & & Ling (2012) & & 3 Esther (2017) & & Singh (2009) & 1 \\
\hline poku (2015b) & & Matinaro (2015) & & Opoku (2015a) & & Ofori-Kuragu (2016) & & Afsar (2018) & 1 & & \\
\hline hen (2017) & & 5 Pirzadeh (2017) & & Pryke (2015) & & Polesie (2012) & & Skeepers (2015) & 1 & & \\
\hline Karakhan (2017a) & & Verstraete (2017) & & Toor $(2011 \mathrm{c})$ & & Terouhid (2016) & 1 & & & & \\
\hline iolet (2016) & & Ozorhon (2016) & & Becker (2014) & & Zilke (2015) & 1 & & & & \\
\hline $\mathrm{Vu}(2017)$ & & Famakin (2016) & & Karallis (2011) & & Pesämaa (2018) & 1 & & & & \\
\hline Indersen (2018) & & Senaratne $(2015 b)$ & & Lukiyanto (2018) & & Kerdngern (2017) & 1 & & & & \\
\hline Theng (2015a) & & Siew (2018) & & Potter (2018) & & $\mathrm{Ni}(2018)$ & 1 & & & & \\
\hline aniel (2015) & & Chang (2016) & & Toor $(2011 b)$ & & Nguyen (2017) & 1 & & & & \\
\hline eschke (2017) & & Mazzetto (2018) & & Wan Muda (2016) & 1 & & & & & & \\
\hline $\operatorname{Jmar}$ (2017) & & Morello (2018) & & & & & & & & & \\
\hline Ven Lim (2018) & & Pushkar (2018) & & & & & & & & & \\
\hline Marín (2017) & & & & & & & & & & & \\
\hline Choi (2018) & & & & & & & & & & & \\
\hline Chang (2018b) & 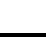 & & & & & & & & & & \\
\hline ot: & 71 & & 631 & & 4 & & 1 & & 5 & & 393 \\
\hline
\end{tabular}

\section{Cluster 1 - Safety}

Literature in cluster 1 focuses on leadership as the most important factor influencing

402 safety on construction projects. Overall, contributions to the cluster characterise leadership as

403 a vertical process whereby leaders maintain assessment, reporting and behavioural standards 
For example, Kines et al. (2010), who make the central contribution to this cluster, investigate whether a relationship exists between the incidence of work-related accidents and leader-based verbal safety communication. To do so they identify vertical 'leader-worker exchanges' in construction projects where supervisors communicate safety expectations to workers (Kines et al. 2010). Centrally, they find that 'coaching construction site foremen to include safety in their daily verbal exchanges with workers has a significantly positive and lasting effect on the level of safety' (Kines et al. 2010). This characterisation of safety leadership as a vertical practice is the dominant paradigm informing research throughout the cluster (Dingsdag et al. 2008; Hoffmeister et al. 2014; Jitwasinkul et al. 2016; Kapp 2012; Khosravi et al. 2014). For example, studying four large commercial construction contractors, Kapp (2012) finds that in positive safety climates, transformational and contingent reward leadership practices improve safety outcomes. Similarly, Dingsdag et al. (2008) consider safety leadership to be a competence enacted by individuals on construction sites, identifying site Occupational Health and Safety (OHS) advisors and site foremen as being primarily responsible for safety outcomes as indicated by their subordinates.

This cluster does contain some research considering how horizontal forms of leadership could simultaneously contribute to safety leadership in construction projects. For example, Williams Jr et al. (2010) find that a horizontal peer-led approach to informing safety culture is an effective way of improving safety outcomes in groups of Latino day construction workers and would ideally coexist alongside vertical leadership practices (Williams Jr et al. 2010).

Similar hybrid approaches to safety leadership are raised by a number of authors in the cluster, indicating that responsibility for safe working environments should be distributed and then reinforced by key individuals, such as site OHS officers and foremen. However, a framework clearly describing the interaction between vertical and horizontal approaches to leadership in safety is yet to be outlined (Biggs et al. 2013; Conchie et al. 2013; Lingard et al. 
2009; Mitropoulos and Cupido 2009). An analysis of recent contributions to the cluster helps

431

432

433

434

435

436

437

438

439

440

441

442

443 identify specific research avenues needing to be addressed. First, the interaction between group leadership, social safety climate and accident self-reporting is yet to be fully understood (Andersen et al. 2018). As Andersen et al. (2018) indicate, hard forms of safety leadership such as punishments for safety misdemeanours, may not prove as effective as softer methods of curating a social climate conducive to strong safety outcomes. Future research needs to consider how 'managerial actions to strengthen workers' social identification with [a] construction project... may lead to the development of a stronger safety climate at the construction site level' (Andersen et al. 2018). The role of self-motivation and self-leadership is also emerging as an important research avenue for construction safety leadership theory (Wen Lim et al. 2018). As self-leadership theory develops, it is important that research considering self-leadership in construction takes into account multi-dimensional characterisations of worker motivation and how these interface with extant vertical leadership practices and shifting group dynamics (Wen Lim et al. 2018; Zhang et al. 2018b).

Overall, research in Cluster 1 considers the vertical leadership of individuals, such as OHS officers or foremen, as critical to strong safety performance. However, recent research has begun considering how vertical leadership may be complemented by horizontal leadership practices, such as team-leadership or self-leadership, but is yet to present a framework that clearly describes this interaction (Andersen et al. 2018; Paunova 2015; Wen Lim et al. 2018). In the balanced leadership framework, horizontal leaders are empowered to foster consensus and workgroup culture at the team level through reflexive communication between teams, project managers and organisation-wide leadership (Müller et al. 2018a). In the framework, the localised autonomy of horizontal leaders to self-manage at a team-level is tempered by their connection to a centralised control layer of permanent vertical leaders (Müller et al. 2018a). In practice, this would see workgroup leaders afforded temporary authority to establish social 
safety cultures for their workgroup to identify with, while ensuring these cultures remain linked to sitewide safety standards enforced by vertical leaders such as foremen and project managers. Therefore, to better understand how vertical leaders can drive safety outcomes through horizontal self-leadership and identification with social safety cultures, future research should build on Andersen et al. (2018) and identify drivers of consensus building within specific onsite workgroups (estimators, electricians, labourers etc). Examples of drivers include storytelling, training or shared technical knowledge (Rowlinson and Jia 2015; Williams Jr et al. 2010). Such research will provide site managers, project managers and supervisors insight into how workgroup autonomy can be balanced with vertical safety oversight, offering a new perspective on how workgroup cultures interact with site level safety.

\section{Cluster 2 - Innovation \& sustainability}

Cluster 2 focusses primarily on how leadership can drive innovation in construction leading to stronger sustainability outcomes. Again, the most frequently cited research in this cluster characterises leadership vertically (Bossink 2004; Gu and London 2010; Limsila and Ogunlana 2008; Ozorhon et al. 2014). However, unlike the other clusters where citations are distributed relatively evenly across the articles contained, cluster 2 is dominated by one contribution in particular which attracts nearly $40 \%$ of all citations in the cluster: $\mathrm{Gu}$ and London (2010). Gu and London (2010) analyse the readiness of the Architecture, Engineering and Construction (AEC) industry to leverage Building Information Modelling (BIM), particularly in relation to sustainable building design, across three dimensions: technology, processes and people. They find a high degree of variance in the readiness of AEC firms to leverage BIM, and propose a framework for BIM adoption, the Collaboration BIM Decision Framework ( $\mathrm{Gu}$ and London 2010). In the framework, interdisciplinary groups of leaders collaborate to enable BIM adoption across four key domains: work processes, resourcing, 
scoping/project initiation and tool mapping (Gu and London 2010). While the degree of vertical leadership required throughout the model varies, central authorities such as senior executives, clients and BIM managers play crucial roles in spearheading BIM adoption (Gu and London 2010). Understanding the implications of BIM for sustainable construction leadership is a recurring concern within the cluster and remains the focus of ongoing research (Tuohy and Murphy 2015; Wallhagen and Glaumann 2011; Wu and Issa 2014).

Research in Cluster 2 also explores the role of vertical leaders in construction innovation more broadly (Limsila and Ogunlana 2008; Ozorhon et al. 2014). Ozorhon et al. (2014), for instance, consider how key individuals such as clients, managing directors and contractors, can be 'innovation champions' in construction projects by setting an empowering example for subordinates. As they note, 'open leaders empower their employees and encourage their creativity: they form an environment that is conducive for innovation' (Limsila and Ogunlana 2008; Ozorhon et al. 2014). Despite evidence from other industries of the benefits of horizontal leadership practices for innovation outcomes (Davis and Eisenhardt 2011; Lindgren and Packendorff 2011; Zhou 2014), there is barely any discussion of horizontal leadership practices in the cluster. The only mention of horizontal leadership comes from Idoro (2009) who flags shared leadership between construction project managers and bank representatives on Nigerian construction projects as hindering project progress and undermining leadership integrity. Given the innovation outcomes achieved through implementation of horizontal leadership practices in entrepreneurial teams (Zhou 2014), R\&D

500 teams (Lindgren and Packendorff 2011), ICT developers (Davis and Eisenhardt 2011), 501 healthcare teams (Kaviani et al. 2017) and design teams (Galli et al. 2017), greater research is needed to understand how horizontal leadership may be combined with existing vertical leadership practices to drive similar outcomes in construction projects. 

with many studies focusing on how longstanding vertical leadership practices support or inhibit emerging innovation and sustainability outcomes (Gu and London 2010; Limsila and Ogunlana 2008; Ozorhon et al. 2014). While it is clear vertical leaders are indispensable as champions of innovation adoption, there has been a lack of research considering how distributed leadership practices complement the role of vertical leaders in facilitating innovation adoption (Gu and London 2010; Wu and Issa 2014). Consideration of balanced leadership theory may encourage greater exploration of how such practices support or inhibit innovation and sustainability outcomes in construction while remaining cognisant of the demonstrated benefits of vertical leadership. For example, future research should consider how building strategic agility by distributing decision making authority horizontally across an assembly of site-level leaders could improve the capacity of construction firms to capitalise on forefront innovation and sustainability frameworks. In particular, researchers should consider whether factors that have been found to influence the readiness of senior leaders to distribute decision making authority in other contexts, such as career expectations, project risk, age and power distance, are equally relevant in construction (Galli et al. 2017; Müller et al. 2018b; Paunova 2015). Advancing construction research in this way will reveal how vertical, horizontal and balanced leadership practices can be best leveraged to accommodate the observed rapidly changing innovation and sustainability agendas.

\section{Cluster 3 - Leadership competence}

Cluster 3 also focusses predominantly on vertical leadership. The cluster draws together strands of broader leadership theory, all of which characterise leading as an individual activity, to critically reflect on key leadership competencies needed to succeed in construction. Overall, research in the cluster indicates that the leadership of project managers is a key determinant of 
project performance and that the most effective project managers demonstrate an ability to adapt their competencies in response to the peculiarities of different project teams, locations and objectives (Enshassi et al. 2009; Odusami 2002). Enshassi et al. (2009), for example, find that a project manager's leadership skills are the paramount driver of performance and client satisfaction on construction projects. Looking more specifically at what skills leaders require, Dainty et al. (2005) develop a competence-based model comprised of 12 core competencies desired for construction project managers. Of these competencies, superior performing project managers exemplify self-control, flexibility, client-oriented focus, impact and influence, and team leadership (Dainty et al. 2005). In a similar study, Odusami (2002) identifies decision making, communication, leadership and motivation, and problem solving as the four most important competencies for effective construction project managers. These studies play a valuable role in informing which competencies are prioritised during the education and selection of project managers, but do not consider how enactment of these competencies may extend beyond individual project managers in practice.

Of note in cluster 3 are the contributions of Toor (2011; 2008a; 2008b; 2008c; 2009; $2010 ; 2011 \mathrm{a} ; 2011 \mathrm{~b})$ that collectively attract over $22 \%$ of citations in the cluster. While these contributions address construction leadership from varying perspectives, a consistent thread throughout them is the notion of authenticity as a core leadership competence. Toor and Ofori (2008b) describe authentic leaders as leaders who 'understand their purpose, practice solid values, lead with heart, establish connected relationships, and demonstrate a high level of selfdiscipline'. Throughout his contributions to the cluster, Toor considers how more authentic approaches to leadership can combat critical sentiment around construction project governance, generating 'a fresh perspective of implicit leadership drives, suitable leadership behaviours for construction projects, practical and authentic performance standards, effective 553 leadership interventions that can help to accelerate leadership development, influence of 
leadership on project outcomes, influence of leadership on followers and organizational outcomes in the long-term' (Toor and Ofori 2008b). This research is largely 'focused on executives, project managers, site managers, quantity surveyors' (Toor and Ofori 2008b), and the authors note that 'it is important to analyze authentic leadership at all levels of construction organizations. Such examinations at dyadic, group, and organizational levels also have the potential to enhance the understanding of authentic leadership in the construction industry'. Recent research has begun to consider the need for authenticity across other on-site leadership roles such as foremen and supervisors, however the role played by authenticity in integrating vertical and horizontal sources of leadership is yet to be studied (Wan Muda et al. 2016). This could render valuable insights regarding the effectiveness of authentic leadership in situations where contrasting purposes, practices and underlying values exist between horizontal leaders.

In sum, cluster 3 demonstrates that leadership competence is considered an individual competencies coalescing in team-level competencies, however, the way in which these teamlevel competencies enable or constrain the integration of vertical and horizontal sources of leadership is unknown (Wan Muda et al. 2016). In contrast, a team-based approach to leadership competence is fundamental to balanced leadership where a focus is placed on a 'candidate's identity, construction and positioning relative to other candidates for horizontal leadership' (Müller et al. 2018b). In other project-based organisations this approach has been found to provide a broad range of leadership competencies across a team by flexibly drawing on a pool of horizontal leaders (Galli et al. 2016).

Therefore, it may be valuable for future research in this cluster to distinguish between competencies that are essential in vertical leaders, such as, for example, communication or selfcontrol (Dainty et al. 2005; Odusami 2002), and competencies that deliver benefit when distributed across workgroups, such as technical proficiency or negotiation (Wan Muda et al. 
579 2016). In practice, this line of research could inform a new perspective on leadership 580 competence in construction firms, prioritising the identification of groups of leaders who

581 collectively share a diverse and dynamic set of competencies tailored to the project at hand 582 rather than searching for individual leaders with perhaps only some of the necessary 583 competencies.

Cluster 4 - Organisational learning

Research in cluster 4 is the most diverse, however the strongest focus of the cluster is on organisational learning (Almaian et al. 2016; Chiang et al. 2008; Chinowsky et al. 2007; DeVilbiss and Leonard 2000; Knauseder et al. 2007; Love et al. 2016; Pham and Swierczek 2006; Pries et al. 2004; Styhre 2011; Styhre and Josephson 2007). This body of research accounts for $41 \%$ of citations in the cluster and will be the focus of this discussion. This research contemplates how different leadership approaches support organisational learning in construction projects.

Chinowsky et al. (2007), for example, compare the learning techniques and technologies of construction and non-construction firms to develop an organisational learning maturity model for construction firms. The model argues that leading for organisational learning requires a somewhat hybrid approach where individual leaders leverage their influence to champion change, followed by distributed organisational learning in response to a new shared vision. However, other than time elapsing, the authors do not explain the mechanisms through which vertical leadership enables distributed learning and so emphasis in their model remains on the vertical leadership of senior executives in facilitating leadership exchange. As implementation of a learning organization culture'. Adopting a similar view, DeVilbiss and 
group processes is critical to effective organisational learning. However, their research lacks critical reflection on the impact of specific aspects of group processes and transformational leadership on organisational learning. Therefore, their partnering framework does not clearly distinguish how vertical and horizontal leadership facilitate organisational learning (DeVilbiss and Leonard 2000).

As cluster 4 demonstrates, organisational learning has recently emerged as a salient concern in the construction industry (Love et al. 2016). Extant literature considers how vertical leaders influences organisational learning and in doing so overlooks how horizontal leaders could either contribute to, or potentially detract from, this influence. This stands in stark contrast to broader organisational learning literature that recognizes organisational learning as collective capacity, so that 'the ideal leader might recognize his or her limitations and share the leadership of organizational learning with colleagues' (Vera and Crossan 2004).

Currently, understanding how this sharing of responsibility for organisational learning should occur in construction is challenging as research identifying precisely how horizontal leadership practices contribute to organisational learning in projects is lacking. Horizontal leadership theory indicates that a combination of horizontal leadership and vertical lines of communication is required to facilitate organisational learning, however, no framework has been proposed for achieving this combination (Denis et al. 2012).

Outside of construction, the balanced leadership archetype explains organisational learning through the notions of mental models and knowledge transfers. It suggests that, while individuals may work in independent teams, they share loose mental models that inform interaction and the transfer of tacit knowledge. Müller et al. (2018a) describe this process as 'a generative dance' between horizontal and vertical leadership, in which 'the horizontal leader interacts with the vertical leader over a period of time to develop the project forward and... reshape, or even abandon their actions and interactions'. On a construction site, this approach 
may manifest as shared learning in workgroups (for instance, estimators, joiners or electricians) facilitated by mid-level managers (for instance site managers, superintendents and project managers) who actively relay learnings to senior off-site leaders. Through this information relay, micro-level learning is inducted and disseminated across the organisation while being validated through vertical leaders (Drouin et al. 2018).

Future research should look to establish empirically how factors such as organisational risk tolerances, resourcing constraints and conflicting knowledge cultures might enable or inhibit the relay and induction of on-site knowledge through mid-level managers (Chinowsky et al. 2007; Godfrey Ochieng and Price 2009; Oladinrin and Ho 2016). Advancing construction leadership research in this manner would establish more clearly how vertical and horizontal leadership practices should be combined to maximize organizational learning.

\section{Cluster 5 - Vision and external engagement}

Cluster 5 looks at the ability of leaders to collaborate with co-workers and external stakeholders through a shared vision. Contributions to the cluster draw on transformational leadership theory (Jiang et al. 2017; Tabassi et al. 2014; Waziri et al. 2015; Zhang et al. 2018c) and emotional intelligence theory (Butler and Chinowsky 2006; Chih et al. 2017; Lee et al. 2005; Zhang et al. 2018a). While still firmly focussed on vertical leadership, research in this cluster also considers horizontal and balanced leadership approaches. Broadly, it is argued that horizontal leadership practices positively impact the effectiveness of vertical leadership in bringing about organisational change (Jiang et al. 2017; Spatz 1999; Tabassi et al. 2014). For example, Jiang et al. (2017) focus on vertical leadership, finding that organizational citizenship behaviour (OCB) has a mediating effect on the effectiveness of transformational leadership initiatives designed to improve sustainability outcomes in Chinese construction. Importantly, key OCB behaviours identified, such as 'helping', 'sportsmanship', 'individual initiative', 
'civic virtue' and 'self-development', align closely with behaviours commonly associated with shared leadership and self-leadership indicating the possibility of a relationship between the approaches in the context of OCB (Denis et al. 2012; Jiang et al. 2017). Similarly, Zhang et al. (2018a) indicate that leader emotional intelligence is positively associated with both transformation leadership and integrated project delivery (IPD), a form of external engagement requiring cooperation between internal and external stakeholders (Zhang et al. 2018a). As a construct, IPD aligns closely with pooled leadership in which responsibility over project critical factors is distributed horizontally across a collaborative leadership team. However, Zhang et al. (2018a) primarily consider whether vertical laissez-faire leadership can stimulate collaborative IPD in construction projects and do not consider horizontal forms of leadership. Contrastingly, Spatz (1999) considers horizontal leadership, indicating that construction firms can pursue their competitive vision most effectively when teams self-lead through shared-leadership. In particular, teams must exhibit communication, honesty, quality, respect and mutual support in order to maintain a consistent vision within and outside of the organisation (Spatz 1999). Likewise, offering a more balanced consideration of both vertical and horizontal leadership approaches, Tabassi et al. (2014) conceptualise leadership as primarily a dynamic group process involving mutual influence geared towards the achievement of goals. They suggest that the paramount goal for transformational leaders in construction is 'developing followers into leaders, inspiring followers to go beyond their own self-interest and giving employee empowerment', thus explicitly recognizing the role of vertical leaders in fostering horizontal leadership (Tabassi et al. 2014).

Based on literature in Cluster 5, what is lacking currently from research addressing vision and external engagement in construction is a clear understanding of how different forms of horizontal leadership influence interactions with clients, contractors, regulators, council representatives and other stakeholders (Tabassi et al. 2014; Zhang et al. 2018a). Such research 
would give a more holistic indication of the mediating influence of mechanisms such as team building, sensemaking, trust, self-leadership and emotional intelligence on the relationship

681 between construction leadership and external engagement (Butler and Chinowsky 2006; Denis et al. 2012; Zhang et al. 2018a). While recent research has indicated that organizational citizen behaviour (OCB) positively influences leadership vision and external engagement on construction projects, it does not establish clearly what aspects of OCB can be considered leadership behaviours and the effect produced by each of these aspects (Zhang et al. 2018a). Overlaps with horizontal leadership theory are frequent in cluster 5, however no studies identify horizontal leadership practices contributing to leadership vision and external engagement, and so there is no consideration as to how these might integrate with extant vertical leadership practices (Jiang, Zhao \& Ni 2017; Tabassi et al. 2014; Waziri, Ali \& Aliagha 2015; Zhang et al. 2018c).

Two practices from the balanced leadership archetype are relevant for considering how vertical and horizontal leadership practices can operate cohesively to improve leadership vision and external engagement: enabling consensus building and defining a control layer. First, through 'group meetings for consensus finding, one-on-one meetings, use of task forces, delegation of leadership and decision making authority', balanced leadership offers a flexible framework centred on building consensus around a shared vision (Müller et al. 2018a). Second, the practice of defining a control layer demonstrates how vertical leaders can govern horizontal leaders without curbing autonomy (Müller et al. 2016).

Therefore, to understand how construction firms integrate vertical and horizontal leadership practices around vision and external engagement, researchers could study how existing consensus finding processes are delegated to workgroups, and subsequently, the mechanisms by which site leaders establish trust and control over these workgroups. In light of the focus of cluster 5, understanding how OCB fits into workgroup level consensus making 
and how transformational leaders maintain trust and control onsite would be promising starting points for future research (Tabassi et al. 2014; Zhang et al. 2018a). As vertical and horizontal forms of leadership coexist more frequently on construction projects, advancing this research avenue would equip practitioners with a clearer understanding of where responsibility for external engagement lies (Tabassi et al. 2014).

\section{Cluster 6 - Leader-follow power dynamics}

Literature in cluster 6 considers construction leadership from the perspective of leaderfollower power dynamics and examines the role of both vertical and horizontal leadership practices. This discussion is particularly salient for construction moving forwards as shifts away from vertical leadership carry inherent challenges to traditional authorities such as project managers and site supervisors (Giritli and Oraz 2004; Kasapoğlu 2014). Citations in the cluster are evenly spread and overall, research in the cluster indicates that leaders who rely on establishing relational, consultative power rather than directive, autocratic power have greater influence on their followers and on project performance (Fellows et al. 2003; Liu et al. 2003; Liu and Fang 2006; Odusami et al. 2003). This is supported by findings by Odusami et al. (2003) who indicate a stronger relationship between power diffused, consultative leadership styles and project performance than non-consultative autocratic styles in construction projects. Likewise, studying Chinese construction projects, Liu and Fang (2006) identify two dimensions of leadership power: power oriented towards performance and power oriented towards maintaining role structure. Overall, they find that performance-oriented leadership power results in the distribution of leadership power and elicits higher project performance through stronger subordinate commitment (Liu and Fang 2006).

While there is some consensus that sharing of power in construction projects through consultative leadership styles has a positive influence on performance, recent research does not 
sufficiently describe which leadership responsibilities are beneficial to distribute and which are not (Kasapoğlu 2014). Singh and Jampel (2010), for instance, argue that 'leadership exists and exercises itself at all levels of the organization' and that 'leadership skills can be built by delegating more work to individuals through increased workload and delegation of adequate power'. However, their research does not describe what constitutes 'adequate power' to provide subordinates and how a balance between inadequate, adequate and excessive distribution of power can be maintained (Singh and Jampel 2010). This is a key gap across the power dynamics literature and so a framework is needed that better describes how project managers, supervisors and other leaders can maintain a suitable balance of power with subordinates (Ameh and Odusami 2014; Giritli et al. 2013; Singh and Jampel 2010).

Overall, a gradual shift away from a focus on autocratic leadership to a more consultative approach has been observed in construction (Liu and Moskvina 2016) and this shift is reflected across cluster 6 (Fellows et al. 2003; Randeree and Chaudhry 2012; Singh and Jampel 2010). While it has been established that a more consultative leadership style 'creates emotional bonds and harmony between the leader and the group and improves positive communication' (Kasapoğlu 2014), ambiguity remains with regard to the types of responsibilities (e.g. supplier management, external engagement, task scheduling) that can be distributed horizontally and how a balance between centralized control and team freedoms can be achieved (Ameh and Odusami 2014; Giritli et al. 2013; Singh and Jampel 2010).

In contrast, the balanced leadership archetype describes how responsibilities can be distributed flexibly while ensuring the remits of horizontal leaders align with project needs. Authority to identify and empower horizontal leaders is retained by permanent vertical leaders to ensure consistency and alignment with firm strategy (Yu et al. 2018). For such an approach to be effective in construction, this control layer of permanent vertical leaders would need to reserve power to grant leadership authority to workgroup members dependent on their 
capabilities and the needs of the project, requiring an acute understanding of the power dynamics at play.

In sum, future research should explore methods for mapping and understanding complex power dynamics within workgroups where temporary horizontal leaders operate in conjunction with vertical authorities (Grisham and Srinivasan 2008; Singh and Jampel 2010). Such research could use the model of Liu and Moskvina (2016) found in Cluster 6 as a starting point, and in doing so, advance a more granular understanding of the effects of balancing leader power dynamics in construction.

\section{Cluster synthesis}

Summarizing insights from the above systematic review, Table 4 below represents how the six research clusters on construction leadership relate to the vertical, horizontal and balanced leadership archetypes. On this basis, vectors for future research are outlined for each cluster. The vectors address a broad range of emerging concerns within construction leadership research and have a practical focus on improving performance outcomes in construction projects. 


\begin{tabular}{|c|c|c|c|c|}
\hline Safety & $\begin{array}{l}\text { - Hard control over safety through the setting of assessment, reporting and behavioural } \\
\text { standards (Kines et al. 2010) } \\
\text { - Soft control over safety through verbal leader-worker exchange (Kines et al. 2010) } \\
\text { - Managing safety cultures through coaching and contingent reward schemes (Kapp 2012) } \\
\text { - Leaders as on-site safe work exemplars (Dingsdag et al. 2008) } \\
\text { - Both transactional and transformational leadership behaviours are positively associated } \\
\text { with safety outcomes except for active management-by-exception (Hoffmeister et al. 2014) } \\
\text { - Good safety leadership facilitated by individual's discipline, values, vision, honesty, } \\
\text { engagement, demonstration and promotion relating to safety outcomes (Daniel 2015) }\end{array}$ & $\begin{array}{l}\text { - Within-group homogeneity \& between-group variation• } \\
\text { encouraging group-level safety climates (Lingard et al. } \\
\text { 2009) } \\
\text { - Pooled supervisory support improves leadership } \\
\text { engagement in safety outcomes (Conchie et al. 2013) } \\
\text { - Task-demand capability model for high reliability } \\
\text { crews (Mitropoulos and Cupido 2009) }\end{array}$ & $\begin{array}{l}\text { Vertical leaders fostering peer- } \\
\text { led safety cultures within teams } \\
\text { (Williams Jr et al. 2010) }\end{array}$ & $\begin{array}{l}\text { - How do vertical leaders in construction drive safety } \\
\text { outcomes by enabling identification with social safety } \\
\text { cultures and horizontal self-leadership? (Andersen et al. } \\
\text { 2018; Rowwinson and Jia 2015; Wen Lim et al. 2018; } \\
\text { Williams Jr et al. 2010) }\end{array}$ \\
\hline $\begin{array}{l}\text { Innovation \& } \\
\text { sustainability }\end{array}$ & $\begin{array}{l}\text { - BIM adoption across work processes, resourcing, scoping/project initiation \& tool mapping } \\
\text { (Gu and London 2010) } \\
\text { - Availability of effective leaders, qualified staff and information/technology are critical } \\
\text { success factors for BIM implementation (Ozorhon and Karahan 2017) } \\
\text { - Senior leaders should serve as innovation champions by demonstrating creativity, vision } \\
\text { and long-term commitment to innovation (Ozorhon et al. 2014) }\end{array}$ & $\begin{array}{l}\text { g Shared leadership constraining innovation through } \\
\text { miscommunication and ambiguous authority (Idoro } \\
\text { 2009) }\end{array}$ & Not represented & $\begin{array}{l}\text { - How does the horizontal distribution of leadership } \\
\text { responsibilitites influence the readiness of construction } \\
\text { firms to capitalize on the ongoing evolutition of innovation } \\
\text { and sustainability frameworks? (e.g. BIM adoption, LEED } \\
\text { certification etc)? (Doan et al. 2017; Pushkar 2018; Wu } \\
\text { and Issa 2014) }\end{array}$ \\
\hline $\begin{array}{l}\text { Leadership } \\
\text { competence }\end{array}$ & $\begin{array}{l}\text { - Superior project managers exemplify self-control, flexibility, client-oriented focus, } \\
\text { impact/influence and team leadership (Dainty et al. 2005) } \\
\text { - Superior project managers exemplify decision making, communication, leadership and } \\
\text { motivation, and problem solving (Odusami 2002) } \\
\text { - Authentic leadership achieved through purpose, values, heart, relationships and self- } \\
\text { discipline is the paramount leadership competency (Toor and Ofori 2008) } \\
\text { - Managerial competence focussed on modelling and enabling expected behaviours is more } \\
\text { desirable than an ability to encourage others through shared vision (Slattery and Sumner } \\
\text { 2011). }\end{array}$ & $\begin{array}{l}\text { - Leadership as a multi-directional social process } \\
\text { informed by team composition and project variables } \\
\text { (Toor and Ofori 2008) } \\
\text { - Family-led firms as a form of pooled-leadership } \\
\text { (Leotta et al. 2017) }\end{array}$ & Not represented & $\begin{array}{l}\text { - What competencies are essential in vertical leaders and } \\
\text { what competencies can be distributed across workgroups? } \\
\text { How can this information inform a team-based approach } \\
\text { to leadership competence in construction? (Dainty et al. } \\
\text { 2005; OOdusami 2002; Toor and Ofori 2008; Wan Muda et } \\
\text { al. 2016) }\end{array}$ \\
\hline $\begin{array}{l}\text { Organisational } \\
\quad \text { learning }\end{array}$ & $\begin{array}{l}\text { - Organisational learning maturity model in which vertical leaders leverage influence to } \\
\text { induce learning around a shared vision (Chinowsky et al .2007) } \\
\text { Transformational leadership is integral to inducing group-level initiative and organisational } \\
\text { learning (DeVilbiss and Leonard 2000) } \\
\text { - Client leadership complements effective firm leadership to accelerate development of } \\
\text { advanced innovation competence and supply chain integration (Manley 2006) }\end{array}$ & Not represented & Not represented & $\begin{array}{l}\text { - What aspects of vertical and horizontal leadership } \\
\text { encourage organisational learning in construction and how } \\
\text { do factors such as organisational risk tolerances, } \\
\text { resourcing constraints and conflicting knowledge cultures } \\
\text { mediate this relationship? (Chinowsky et al. 2007; } \\
\text { Godfrey Ochieng and Price 2009; Oladinin and Ho 2016) }\end{array}$ \\
\hline $\begin{array}{c}\text { Vision \& } \\
\text { External } \\
\text { engagement }\end{array}$ & $\begin{array}{l}\text { - Transformational leadership, comprised of idealized influence, inspiration, motivation, } \\
\text { intellectual stimulation and individualised consideration, has a positive influence on ICT } \\
\text { adoption (Waziri et al al. 2015) } \\
\text { - Emotional intelligence as a driver of performance in construction executives (Butler and } \\
\text { Chinowsky 2006) } \\
\text { - Vertical leadership style as an antecedent of IPD between internal and external stakeholders } \\
\text { (Zhang te al. 2018) } \\
\text { - Organisational citizenship as a mediator of external engagement through transformational } \\
\text { leadership (Jiang et al. 2017) }\end{array}$ & $\begin{array}{l}\text { - Self-managed teams exhibiting shared leadership } \\
\text { through communication, honesty, quality, respect and } \\
\text { mutual support are essential for maintaining an } \\
\text { internally and externally consistent vision (Spatz } \\
\text { 1999) } \\
\text { rs }\end{array}$ & $\begin{array}{l}\text { - Leadership must be a dynamic } \\
\text { group process instigated by } \\
\text { vertical leaders and implemented } \\
\text { by horizontal leaders (Tabassi et } \\
\text { al. 2014). }\end{array}$ & $\begin{array}{l}\text { - How do vertical leaders establish trust and control with } \\
\text { horizontal leaders while delegating consensus finding } \\
\text { d processes used to improve vision and external } \\
\text { t engagement? What are the mechanisms that mediate the } \\
\text { impacts of these processes and how do they operate when } \\
\text { leadership stems from both vertical and horizontal } \\
\text { sources? (Esther Paik et al. 2017; Jiang et al. 2017; Spatz } \\
\text { 1999; Tababsi et al. 2014; Zhang et al. 2018) }\end{array}$ \\
\hline $\begin{array}{c}\text { Power } \\
\text { dynamics }\end{array}$ & $\begin{array}{l}\text { - Effective project managers demonstrate a combination of authoritative leadership and } \\
\text { technical expertise resulting in lower levels of delegation (Giritli and Oraz 2004) } \\
\text { - Performance-oriented expression of leader power elicits higher performance than structure- } \\
\text { oriented expressions of leader power (Liu and Fang 2006) } \\
\text { - Leadership power should be maintained at all levels of an organisation through delegation } \\
\text { (Singh and Jampel 2010). } \\
\text { - Lower power-distance leadership styles such as consultative or supportive leadership } \\
\text { achieve stronger follower-perceived performance and group satisfaction (Fellows et al. } \\
\text { 2003) }\end{array}$ & - & Not represented & $\begin{array}{l}\text { - How do vertical leaders in construction empower } \\
\text { horizontal leaders while retaining control over } \\
\text { redistribution of leadership authority as project } \\
\text { circumstances change? What methods are available for } \\
\text { mapping and understanding complex power dynamics } \\
\text { within workgroups where temporary horizontal leaders } \\
\text { operate in conjunction with vertical authorities? (Ameh } \\
\text { and Odusami 2014; Giritli et al. 2013; Liu and Moskvina } \\
\text { 2016; Singh and Jampel 2010) }\end{array}$ \\
\hline
\end{tabular}




\section{DISCUSSION}

The current review has been inspired by 'the call for better leadership [that] can be heard throughout the engineering and construction communities' (Simmons et al. 2017). While it is evident that construction leadership practice is changing, research has lacked a robust research agenda to ensure changes are commensurate with emerging challenges, creating a disconnect between theory and practice (Simmons et al. 2017). As the industry responds to challenges in the six areas highlighted by this review, it is critical researchers and practitioners alike are bolstered with more than a single leadership framework to inform the delivery of projects. To address this gap, this review has systematically sampled, synthesized and analysed 289 relevant articles to produce a tri-archetype research agenda aligned to these challenges. In doing so, it makes key contributions to leadership theory in construction and to research in engineering management more broadly.

From a theoretical perspective, this review demonstrates that construction leadership research does not sufficiently explain how the vertical and horizontal leadership archetypes can be successfully integrated despite growing evidence of traditional forms of vertical leadership being supplemented by new types of leadership in practice (Tabassi et al. 2014). The vertical leadership archetype has dominated construction leadership research with only a small number of studies considering the horizontal leadership archetype. Given the thoroughly developed body of horizontal leadership literature found in broader research (Denis et al. 2012) as well as evidence of horizontal leadership in practice (e.g., Harris and McCaffer 2013), this demonstrates both a lag in construction leadership theory and a valuable opportunity to more deeply integrate construction leadership research with contemporary leadership practice. Research in other project industries has found horizontal leadership practices to boost team coordination (Carte et al. 2006; Galli et al. 2016; Hsu et al. 2017; Sullivan et al. 2015), increase the ability of organisations to cope with change (Chreim et al. 2010; Kempster et al. 2014; 

leadership has also been found to dramatically improve the effectiveness of agile approaches to project delivery in other industries (Bäcklander 2018; Dybå et al. 2014; Li et al. 2018; Moe et al. 2015; Moe et al. 2019; Xu and Shen 2018). With construction projects increasingly taking advantage of more flexible agile methods (De Marco 2018; Mendez 2018; Saini et al. 2018), it is imperative that more research is conducted to establish what horizontal leadership practices are currently being used in the industry, whether their effects are comparable to other projectbased industry contexts and what other leadership practices may be valuable to implement moving forwards. The current review sets out a clear agenda for this research. leadership practices should not supersede the valuable roles vertical leaders play, but rather, be integrated to enhance organisational leadership holistically (Müller et al. 2018b). As Denis et al. (2012) echo, 'the field of leadership does not necessarily gain by moving from a view of leadership as individual heroism toward an equally naive democratic ideal in which leadership is an organizational quality shared by all'. Research in other contexts has highlighted tension between vertical and horizontal leadership which could make their integration challenging. paradigm to a leader to leader paradigm (Gronn 2002). Ongoing challenges also rise once vertical and horizontal leadership are operating in conjunction. For both archetypes to exist simultaneously, a high degree of trust is required amongst team members, otherwise, challenges to leadership legitimacy can impede work (Kakar 2017).

The current review shows that these tensions between vertical and horizontal leadership are understudied in construction research which limits the usefulness of extant research for organizations seeking to (further) integrate horizontal leadership practices. The research 
agenda put forward by this review identifies six key areas where a more rigorous theoretical conception of the integration of horizontal leadership practices is crucial: building culture and consensus around worker safety identities (Andersen et al. 2018; Choi et al. 2017; Wen Lim et al. 2018; Wu et al. 2016), integration of technical innovations and sustainability frameworks with extant delivery processes (Bilal et al. 2016; Ozorhon and Karahan 2017; Papajohn et al. 2017; Pushkar 2018), tailoring leadership competence to anticipated project demands (ElGohary and Aziz 2014; Mikaelsson and Larsson 2017; Wan Muda et al. 2016), transmission of knowledge throughout teams (Love et al. 2016; Ni et al. 2018; Oladinrin and Ho 2016), establishing trust and vision in external engagement (Afsar and Shahjehan 2018; Esther Paik et al. 2017; Liu and Chan 2017; Zhang et al. 2018a) and finally, managing transient shifts in on-site power dynamics (Ameh and Odusami 2014; Liu and Fang 2006; Liu and Moskvina 2016). By identifying these six emerging research areas, this review draws together a diverse range of theoretical perspectives to bring much-needed structure to the future of construction leadership research.

The findings of this review should be seen as a stepping stone towards bringing construction leadership research in line with broader leadership theory. In response to the repeated finding that the use of horizontal leadership practices in construction is currently theoretically underdeveloped, this review considers how the emerging balanced leadership archetype may have utility for construction researchers looking to understand how vertical and horizontal leadership practices can coexist effectively. At its core, the archetype is concerned with rapidly connecting the efforts of permanent or semi-permanent vertical leaders with those of temporary horizontal leaders through a framework spanning from the inception to the completion of projects (Müller et al. 2018a). It is the suggestion of this review, based on research linking balanced leadership to positive outcomes in transferring knowledge, consensus building and organizational agility, that the balanced leadership archetype has 
relevance to the challenges faced in construction. Overall, the findings of this review signpost a new direction for construction leadership research and practice that responds to the suggestion that 'construction might benefit from more contemporary frames that foster a more holistic view' on leadership (Simmons et al. 2017).

While the analytic focus of this review is limited to the construction industry, its findings have significance for the broader body of knowledge in engineering management. Research indicates that leaders across the broader field of engineering face many of the same challenges described throughout this review. Lines and Reddy Vardireddy (2017), for instance, study a wide range of engineering professions, arguing that 'to adopt organizational change has become a core competency'. They cite how key technical developments including 'building information modelling', 'virtual design', ‘e-document management', 'modular techniques’ and 'advanced work packaging' are disrupting traditional operating and competitive environments, requiring stronger leadership (Lines and Reddy Vardireddy 2017). Likewise, Perry et al. (2017) highlight the incompatibility of existing frames of thought around engineering leadership given the increasingly collaborative and interdisciplinary nature of projects, leading to the suggestion that 'a revised leadership development model is needed'. Given the evidence that engineering faces a similar set of leadership concerns to those identified in the context of construction, it is likely the findings of this review, which recommend balanced leadership as a promising approach that enables the integration of vertical and horizontal leadership practices, are relevant to the development of leadership research agendas across a broad range of engineering professions (Hartmann et al. 2017; Kameo 2017; Knight and Novoselich 2017; Lines and Reddy Vardireddy 2017; Perry et al. 2017; Rosch and Imoukhuede 2016; Stephens and Rosch 2015).

This research agenda may also herald significant change for practitioners in construction which could be extended to practitioners in engineering contexts. While the six 
research vectors identified in this review consistently indicate that construction leadership theory is significantly lagging behind practice within and beyond construction, the review offers insight into what may be expected of construction leaders in the future. With firmer theoretical frameworks around the sharing of responsibilities, the roles of existing leaders in construction, such as executives, project managers, site managers and foremen, will be reframed as they become increasingly valued as expert integrators in a complex web of leaders rather than as experts in a particular discipline. Therefore, as the industry moves away from task-oriented leadership towards more co-operative approaches, vertical leaders will need to complement their deep technical competence with an ability to integrate a wide range of information, foster collaboration, share responsibilities and exert control through softer, less formal means such as relationships and social cultures (Shirazi et al. 1996). Leaders' professional development efforts need to be tailored towards becoming proficient in these softer practices associated with building team competence for knowledge sharing and problem solving. As Clarke (2012) echoes, 'the problem is one of developing an enhanced problemsolving capacity that necessitates high levels of knowledge sharing, and a greater potential for more rapid and effective responses to escalating events through emergent leadership capabilities'.

This review highlights a lag in construction leadership theory accurately reflecting current practice. As theory catches up and develops stronger frameworks to describe horizontal and balanced leadership practices in construction, it is important that consideration is given to identifying where tension may arise between these archetypes. For instance, tension may arise as formal and informal leadership authorities share power in different arrangements (Shirazi et al. 1996). The training and development of future leaders changes in response to the increasing transience of leadership positions available (Fellows et al. 2009) and information must be increasingly shared horizontally between leaders (Harris and McCaffer 2013). It is therefore 
crucial that construction leadership theory supports vertical and horizontal leaders by providing frameworks that inform what leadership responsibilities should be distributed, how they are to be distributed and when they can be distributed. The emerging balanced leadership approach provides relevant insights into the practices vertical leaders can adopt to facilitate horizontal leadership in a way that avoid tensions and more research in this area will provide further valuable insights to practitioners. Further, vertical leaders must develop stronger capabilities for facing complex power dynamics in their organizations so that they can adapt their leadership to match transient distributions of decision-making authority. With significant changes on the horizon for construction firms, it is hoped the research agenda outlined by this review will inform forthcoming leadership research and guide practitioners towards practices better suited to the challenges identified.

It is important to highlight some limitations of this review. First, while the bibliometric review methodology used in this paper has been found to identify connections between articles more accurately than through an entirely manual review, it can never offer a perfectly objective assessment as researcher input will inevitably be required in the sample selection stage (Booth et al. 2016; Boyack and Klavans 2010). In the current paper researcher influence has been minimized through clearly defined search parameters, journal quality controls and the independent comparison of abstracts with exclusion criteria by each author (Randhawa et al. 2016). Second, while there is evidence to suggest that the results of this review hold relevance beyond the construction industry (Lines and Reddy Vardireddy 2017; Perry et al. 2017), the sampling process implemented ensures the results presented and the associated research agenda refer explicitly to the construction industry. Given that similar leadership concerns have been identified throughout the broader body of research in engineering management, it is important that future studies conduct similar systematic reviews across other engineering industries to establish parallels and differences in professional practice and needs more acutely. Finally, as 
this review is conceptual in nature, it can only theorize potentially valuable directions for construction leadership theory and practice. Further empirical research will be needed to establish the extent to which a balanced leadership framework is already being implemented in construction practice and evaluate its efficacy with regard to emerging challenges along the six vectors identified in this review. Such research would not only advance construction leadership research but also the new and rapidly growing body of balanced leadership research.

\section{CONCLUSION}

With construction leaders facing increasingly complex challenges, recognition of the need for more diverse frames in construction leadership research has seen increasing use of horizontal leadership practices. The key challenge for construction research will be keeping up with this move away from traditional conceptions of leadership centred on vertical leaders, to develop more integrative frameworks that incorporate both vertical and horizontal leadership practices in a cohesive and practical manner. This review has systematically identified six areas in which there is ambiguity about what construction leadership will look like in the future. In response, the review has provided key research questions to spur on further research and inform practice. While construction leadership research must incorporate many different approaches, consideration of the balanced leadership framework as proposed in this review outlines a promising avenue for future research and practice. 
Abdallah, M., and El-Rayes, K. (2016). "Multiobjective optimization model for maximizing sustainability of existing buildings." Journal of Management in Engineering, 32(4).

Abdul Rahman, I., Memon, A. H., Karim, A., and Tarmizi, A. (2013). "Significant factors causing cost overruns in large construction projects in Malaysia." Journal of Applied Science, 13(2), 286-293.

Abrahms, M., and Mierau, J. (2017). "Leadership matters: The effects of targeted killings on militant group tactics." Terrorism Polit. Violence, 29(5), 830-851.

Adapa, S. (2018). "Indian smart cities and cleaner production initiatives - Integrated framework and recommendations." Journal of Cleaner Production, 172, 3351-3366.

Afsar, B., and Shahjehan, A. (2018). "Linking ethical leadership and moral voice: The effects of moral efficacy, trust in leader, and leader-follower value congruence." Leadership and Organization Development Journal, 39(6), 775-793.

Aghaei Chadegani, A., Salehi, H., Yunus, M., Farhadi, H., Fooladi, M., Farhadi, M., and Ale Ebrahim, N. (2013). "A comparison between two main academic literature collections: Web of Science and Scopus databases."

Allport, G. W. (1937). Personality, Holt New York.

Almaian, R. Y., Needy, K. L., Alves, T. D. C. L., and Walsh, K. D. (2016). "Analyzing Effective Supplier-Quality-Management Practices Using Simple Multiattribute Rating Technique and Value-Focused Thinking." Journal of Management in Engineering, 32(1).

Ameh, O. J., and Odusami, K. T. (2014). "The leadership profile of Nigerian construction project managers." Sci. Iran., 21(4), 1241-1248.

Andersen, L. P., Nørdam, L., Joensson, T., Kines, P., and Nielsen, K. J. (2018). "Social identity, safety climate and self-reported accidents among construction workers." Construction Management and Economics, 36(1), 22-31.

Annan, J. S., Addai, E. K., and Tulashie, S. K. (2015). "A Call for Action to Improve Occupational Health and Safety in Ghana and a Critical Look at the Existing Legal Requirement and Legislation." Saf. Health Work, 6(2), 146-150.

Bäcklander, G. (2018). "Doing complexity leadership theory: How agile coaches at Spotify practise enabling leadership." Creativity and Innovation Management.

Ball, M. (2014). Rebuilding Construction (Routledge Revivals): Economic Change in the British Construction Industry, Routledge.

Bass, B. M. (1991). "From transactional to transformational leadership: Learning to share the vision." Organizational dynamics, 18(3), 19-31.

Beck, A. P. (1981). "A study of group phase development and emergent leadership." Group, 5(4), 48-54.

Biggs, S. E., Banks, T. D., Davey, J. D., and Freeman, J. E. (2013). "Safety leaders' perceptions of safety culture in a large Australasian construction organisation." Safety Science, 52, 3-12.

Bilal, M., Oyedele, L. O., Qadir, J., Munir, K., Ajayi, S. O., Akinade, O. O., Owolabi, H. A., Alaka, H. A., and Pasha, M. (2016). "Big Data in the construction industry: A review of present status, opportunities, and future trends." Advanced Engineering Informatics, 30(3), 500-521.

Blondel, V. D., Guillaume, J.-L., Lambiotte, R., and Lefebvre, E. (2008). "Fast unfolding of communities in large networks." Journal of statistical mechanics: theory and experiment, 2008(10), P10008.

Bolden, R. (2011). "Distributed leadership in organizations: A review of theory and research." International Journal of Management Reviews, 13(3), 251-269. 
Booth, A., Sutton, A., and Papaioannou, D. (2016). Systematic approaches to a successful literature review, Sage.

Bossink, B. A. G. (2004). "Effectiveness of innovation leadership styles: A manager's influence on ecological innovation in construction projects." Construction Innovation, 4(4), 211-228.

Boyack, K. W., and Klavans, R. (2010). "Co-citation analysis, bibliographic coupling, and direct citation: Which citation approach represents the research front most accurately?" Journal of the American Society for Information Science and Technology, 61(12), 2389-2404.

Brereton, P., Kitchenham, B. A., Budgen, D., Turner, M., and Khalil, M. (2007). "Lessons from applying the systematic literature review process within the software engineering domain." Journal of systems and software, 80(4), 571-583.

Bruyelle, J. L., O'Neill, C., El-Koursi, E. M., Hamelin, F., Sartori, N., and Khoudour, L. (2014). "Improving the resilience of metro vehicle and passengers for an effective emergency response to terrorist attacks." Safety Science, 62, 37-45.

Butler, C. J., and Chinowsky, P. S. (2006). "Emotional intelligence and leadership behavior in construction executives." Journal of Management in Engineering, 22(3), 119-125.

Carlyle, T. (1840). On heroes, hero-worship, and the heroic in history, Univ of California Press.

Carte, T. A., Chidambaram, L., and Becker, A. (2006). "Emergent leadership in self-managed virtual teams: A longitudinal study of concentrated and shared leadership behaviors." Group Decision and Negotiation, 15(4), 323-343.

Cavaleri, S., and Reed, F. (2008). "Leading dynamically complex projects." International Journal of Managing Projects in Business, 1(1), 71-87.

Chan, I. Y. S., Liu, A. M. M., and Fellows, R. (2014). "Role of leadership in fostering an innovation climate in construction firms." Journal of Management in Engineering, 30(6).

Chang, R. D., Zuo, J., Soebarto, V., Zhao, Z. Y., Zillante, G., and Gan, X. L. (2016). "Sustainability transition of the Chinese construction industry: Practices and behaviors of the leading construction firms." Journal of Management in Engineering, 32(4).

Chedia, B. (2014). "The paradigm of post-soviet political leadership in georgia." Cent. Asia Cauc., 15(3), 135-144.

Chiang, Y. H., Tang, B. S., and Wong, F. (2008). "Volume building as competitive strategy." Construction Management and Economics, 26(2), 161-176.

Chih, Y. Y., Kiazad, K., Cheng, D., Lajom, J. A. L., and Restubog, S. L. D. (2017). "Feeling Positive and Productive: Role of Supervisor-Worker Relationship in Predicting Construction Workers' Performance in the Philippines." Journal of Construction Engineering and Management, 143(8).

Chinowsky, P., Molenaar, K., and Realph, A. (2007). "Learning organizations in construction." Journal of Management in Engineering, 23(1), 27-34.

Choi, B., Ahn, S., and Lee, S. (2017). "Construction Workers' Group Norms and Personal Standards Regarding Safety Behavior: Social Identity Theory Perspective." Journal of Management in Engineering, 33(4).

Chreim, S., Williams, B. B., Janz, L., and Dastmalchian, A. (2010). "Change agency in a primary health care context: The case of distributed leadership." Health Care Management Review, 35(2), 187-199.

Clarke, N. (2012). "Shared leadership in projects: a matter of substance over style." Team Performance Management: An International Journal, 18(3/4), 196-209. 
Cohen, R. S., and Scheinmann, G. M. (2014). "Can Europe Fill the Void in U.S. Military Leadership?" Orbis, 58(1), 39-54.

Conchie, S. M., Moon, S., and Duncan, M. (2013). "Supervisors' engagement in safety leadership: Factors that help and hinder." Safety Science, 51(1), 109-117.

Dainty, A. R. J., Cheng, M. I., and Moore, D. R. (2005). "Competency-based model for predicting construction project managers' performance." Journal of Management in Engineering, 21(1), 2-9.

Davis, J. P., and Eisenhardt, K. M. (2011). "Rotating leadership and collaborative innovation recombination processes in symbiotic relationships." Administrative Science Quarterly, 56(2), 159-201.

Day, D. V., Gronn, P., and Salas, E. (2004). "Leadership capacity in teams." The Leadership Quarterly, 15(6), 857-880.

De Marco, A. (2018). "Project management organization." Project management for facility constructions, Springer, 57-69.

Denis, J.-L., Lamothe, L., and Langley, A. (2001). "The dynamics of collective leadership and strategic change in pluralistic organizations." Academy of Management Journal, 44(4), 809-837.

Denis, J.-L., Langley, A., and Sergi, V. (2012). "Leadership in the plural." The Academy of Management Annals, 6(1), 211-283.

DeVilbiss, C. E., and Leonard, P. (2000). "Partnering is the foundation of a Learning Organization." Journal of Management in Engineering, 16(4), 47-57.

Dingsdag, D. P., Biggs, H. C., and Sheahan, V. L. (2008). "Understanding and defining OH\&S competency for construction site positions: Worker perceptions." Safety Science, 46(4), 619-633.

Doloi, H. (2012). "Cost overruns and failure in project management: Understanding the roles of key stakeholders in construction projects." Journal of Construction Engineering and Management, 139(3), 267-279.

Drath, W. H., McCauley, C. D., Palus, C. J., Van Velsor, E., O'Connor, P. M., and McGuire, J. B. (2008). "Direction, alignment, commitment: Toward a more integrative ontology of leadership." The leadership quarterly, 19(6), 635-653.

Drouin, N., Müller, R., Sankaran, S., and Vaagaasar, A. L. (2018). "Balancing vertical and horizontal leadership in projects: Empirical studies from Australia, Canada, Norway and Sweden." International Journal of Managing Projects in Business, 11(4), 9861006.

Dubey, R., Gunasekaran, A., and Samar Ali, S. (2015). "Exploring the relationship between leadership, operational practices, institutional pressures and environmental performance: A framework for green supply chain." Int J Prod Econ, 160, 120-132.

Dybå, T., Dingsøyr, T., and Moe, N. B. (2014). "Agile project management." Software project management in a changing world, Springer, 277-300.

El-Gohary, K. M., and Aziz, R. F. (2014). "Factors influencing construction labor productivity in Egypt." Journal of Management in Engineering, 30(1), 1-9.

Enshassi, A., Mohamed, S., and Abushaban, S. (2009). "Factors affecting the performance of Construction projects in the Gaza Strip." Journal of Civil Engineering and Management, 15(3), 269-280.

Esther Paik, J., Miller, V., Mollaoglu, S., and Aaron Sun, W. (2017). "Interorganizational Projects: Reexamining Innovation Implementation via IPD Cases." Journal of Management in Engineering, 33(5).

Fellows, R., Liu, A., and Fong, C. M. (2003). "Leadership style and power relations in quantity surveying in Hong Kong." Construction Management and Economics, 21(8), 809-818. 
Fellows, R. F., Langford, D., Newcombe, R., and Urry, S. (2009). Construction management in practice, John Wiley \& Sons.

Fiedler, F. E. (1964). "A contingency model of leadership effectiveness." Advances in experimental social psychology, 1(1), 149-190.

Galli, B. J., Santos-Arteaga, F. J., Kaviani, M. A., and Mohebbi, C. (2017). "An experimental design for optimising the degree of shared leadership in senior engineering design teams." International Journal of Knowledge Engineering and Data Mining, 4(2), 157 186.

Galli, B. J., Szabat, K., Mohebbi, C., and Ugras, Y. J. (2016). "An investigation in how six sigma project teams should make rational decisions in shared leadership environments." Int. J. Enterp. Inf. Syst., 12(4), 47-69.

Gibb, C. A. (1954). "Leadership. In Lindzey, G. (ed.)." Handbook of social psychology, 2, 877-917.

Giritli, H., Öney-Yazici, E., Topçu-Oraz, G., and Acar, E. (2013). "The interplay between leadership and organizational culture in the Turkish construction sector." International Journal of Project Management, 31(2), 228-238.

Giritli, H., and Oraz, G. T. (2004). "Leadership styles: Some evidence from the Turkish construction industry." Construction Management and Economics, 22(3), 253-262.

Gmür, M. (2003). "Co-citation analysis and the search for invisible colleges: A methodological evaluation." Scientometrics, 57(1), 27-57.

Godfrey Ochieng, E., and Price, A. D. (2009). "Framework for managing multicultural project teams." Engineering, Construction and Architectural Management, 16(6), 527-543.

Grisham, T., and Srinivasan, P. (2008). "Temporary project cultures." Int. J. Hum. Resour. Dev. Manage., 8(3), 271-288.

Gronn, P. (2002). "Distributed leadership as a unit of analysis." The leadership quarterly, 13(4), 423-451.

$\mathrm{Gu}, \mathrm{N}$., and London, K. (2010). "Understanding and facilitating BIM adoption in the AEC industry." Autom Constr, 19(8), 988-999.

Guo, S., Shen, B., Choi, T. M., and Jung, S. (2017). "A review on supply chain contracts in reverse logistics: Supply chain structures and channel leaderships." J. Clean. Prod., 144, 387-402.

Harris, A., and Gronn, P. (2008). "The future of distributed leadership." Journal of Educational Administration, 46(2), 141-158.

Harris, F., and McCaffer, R. (2013). Modern construction management, John Wiley \& Sons. Hartmann, B. L., Stephens, C. M., and Jahren, C. T. (2017). "Validating the Importance of Leadership Themes for Entry-Level Engineering Positions." Journal of Professional Issues in Engineering Education and Practice, 143(1).

Heenan, D. A., and Bennis, W. (1999). Co-leaders: The power of great partnerships, John Wiley \& Sons.

Hoffmeister, K., Gibbons, A. M., Johnson, S. K., Cigularov, K. P., Chen, P. Y., and Rosecrance, J. C. (2014). "The differential effects of transformational leadership facets on employee safety." Safety Science, 62, 68-78.

Holly, D., Swanson, V., Cachia, P., Beasant, B., and Laird, C. (2017). "Development of a behaviour rating system for rural/remote pre-hospital settings." Applied Ergonomics, $58,405-413$.

Hsu, J. S. C., Li, Y., and Sun, H. (2017). "Exploring the interaction between vertical and shared leadership in information systems development projects." International Journal of Project Management, 35(8), 1557-1572. 
Hu, N., Chen, Z., Gu, J., Huang, S., and Liu, H. (2017). "Conflict and creativity in interorganizational teams: The moderating role of shared leadership." Int. J. Confl. Manage., 28(1), 74-102.

Idoro, G. I. (2009). "Clients' perception of construction project leaders in the Nigerian banking industry." J. Eng. Des. Technol., 7(3), 264-281.

Iorio, J., and Taylor, J. E. (2015). "Precursors to engaged leaders in virtual project teams." International Journal of Project Management, 33(2), 395-405.

Jeschke, K. C., Kines, P., Rasmussen, L., Andersen, L. P. S., Dyreborg, J., Ajslev, J., Kabel, A., Jensen, E., and Andersen, L. L. (2017). "Process evaluation of a Toolbox-training program for construction foremen in Denmark." Safety Science, 94, 152-160.

Jiang, W., Zhao, X., and Ni, J. (2017). "The impact of transformational leadership on employee sustainable performance: The mediating role of organizational citizenship behavior." Sustainability, 9(9).

Jitwasinkul, B., Hadikusumo, B. H. W., and Memon, A. Q. (2016). "A Bayesian Belief Network model of organizational factors for improving safe work behaviors in Thai construction industry." Safety Science, 82, 264-273.

Kakar, A. K. (2017). "Investigating the Prevalence and Performance Correlates of Vertical Versus Shared Leadership in Emergent Software Development Teams." Information Systems Management, 34(2), 172-184.

Kameo, N. (2017). "A Culture of Uncertainty: Interaction and Organizational Memory in Software Engineering Teams under a Productivity Scheme." Organization Studies, 38(6), 733-752.

Kapp, E. A. (2012). "The influence of supervisor leadership practices and perceived group safety climate on employee safety performance." Safety Science, 50(4), 1119-1124.

Karakhan, A. A., and Gambatese, J. A. (2017). "Identification, quantification, and classification of potential safety risk for sustainable construction in the United States." Journal of Construction Engineering and Management, 143(7).

Kasapoğlu, E. (2014). "Leadership styles in architectural design offices in Turkey." Journal of Construction Engineering and Management, 140(2).

Kaviani, M. A., Galli, B. J., Bottani, E., and Murino, T. (2017). "Shared Leadership and Key Innovation Indicators in Six Sigma Projects." International Journal of Strategic Decision Sciences, 8(4), 1-45.

Keller, K., and Matusitz, J. (2015). "Examining U.S. Navy SEALs Through Cognitive Resources Theory (CRT)." J. Appl. Secur. Res., 10(3), 317-329.

Kempster, S., Higgs, M., and Wuerz, T. (2014). "Pilots for change: Exploring organisational change through distributed leadership." Leadership and Organization Development Journal, 35(2), 152-167.

Khosravi, Y., Asilian-Mahabadi, H., Hajizadeh, E., Hassanzadeh-Rangi, N., Bastani, H., and Behzadan, A. H. (2014). "Factors influencing unsafe behaviors and accidents on construction sites: A review." Int. J. Occup. Saf. Ergon., 20(1), 111-125.

Kines, P., Andersen, L. P. S., Spangenberg, S., Mikkelsen, K. L., Dyreborg, J., and Zohar, D. (2010). "Improving construction site safety through leader-based verbal safety communication." Journal of Safety Research, 41(5), 399-406.

Kitchenham, B., Brereton, O. P., Budgen, D., Turner, M., Bailey, J., and Linkman, S. (2009). "Systematic literature reviews in software engineering-a systematic literature review." Inf Software Technol, 51(1), 7-15.

Knauseder, I., Josephson, P. E., and Styhre, A. (2007). "Learning approaches for housing, service and infrastructure project organizations." Construction Management and Economics, 25(8), 857-867. 
Knight, D. B., and Novoselich, B. J. (2017). "Curricular and Co-curricular Influences on Undergraduate Engineering Student Leadership." Journal of Engineering Education, 106(1), 44-70.

Larsson, J., Eriksson, P. E., Olofsson, T., and Simonsson, P. (2015). "Leadership in civil engineering: Effects of project managers' leadership styles on project performance." Journal of Management in Engineering, 31(6).

Lee, D. S., Lee, K. C., Seo, Y. W., and Choi, D. Y. (2015). "An analysis of shared leadership, diversity, and team creativity in an e-learning environment." Comput. Hum. Behav., 42, 47-56.

Lee, T. S., Lee, D. W., Lee, H., and Park, H. S. (2005). "Superior-subordinate relationships in Korean civil engineering companies." Journal of Management in Engineering, 21(4), 159-163.

Li, Y., Sun, H., Shih, S.-P., and Hsu, J. S.-C. (2018). "Shared leadership and technology tools in ISD process."

Limsila, K., and Ogunlana, S. O. (2008). "Performance and leadership outcome correlates of leadership styles and subordinate commitment." Engineering, Construction and Architectural Management, 15(2), 164-184.

Lindgren, M., and Packendorff, J. (2011). "Issues, responsibilities and identities: A distributed leadership perspective on biotechnology R\&D management." Creativity and Innovation Management, 20(3), 157-170.

Lines, B. C., Perrenoud, A. J., Sullivan, K. T., Kashiwag, D. T., and Pesek, A. (2017). "Implementing Project Delivery Process Improvements: Identification of Resistance Types and Frequencies." Journal of Management in Engineering, 33(1).

Lines, B. C., and Reddy Vardireddy, P. K. (2017). "Drivers of Organizational Change within the AEC Industry: Linking Change Management Practices with Successful Change Adoption." Journal of Management in Engineering, 33(6).

Lingard, H. C., Cooke, T., and Blismas, N. (2009). "Group-level safety climate in the Australian construction industry: Within-group homogeneity and between-group differences in road construction and maintenance." Construction Management and Economics, 27(4), 419-432.

Liu, A., Fellows, R., and Fang, Z. (2003). "The power paradigm of project leadership." Construction Management and Economics, 21(8), 819-829.

Liu, A. M. M., and Chan, I. Y. S. (2017). "Understanding the Interplay of Organizational Climate and Leadership in Construction Innovation." Journal of Management in Engineering, 33(5).

Liu, A. M. M., and Fang, Z. (2006). "A power-based leadership approach to project management." Construction Management and Economics, 24(5), 497-507.

Liu, J., and Moskvina, A. (2016). "Hierarchies, ties and power in organizational networks: model and analysis." Soc. Netw. Analysis Min., 6(1).

Love, P. E. D., Ackermann, F., Carey, B., Morrison, J., Ward, M., and Park, A. (2016). "Praxis of rework mitigation in construction." Journal of Management in Engineering, 32(5).

Mendez, A. H. (2018). "Improving Project Performance through Implementation of Agile Methodologies in the Renewable Energy Construction Industry." The George Washington University.

Mikaelsson, L. A., and Larsson, J. (2017). "Integrated planning for sustainable building production-an evolution over three decades." Journal of Civil Engineering and Management, 23(2), 319-326. 
Mitropoulos, P., and Cupido, G. (2009). "The role of production and teamwork practices in construction safety: A cognitive model and an empirical case study." Journal of Safety Research, 40(4), 265-275.

Moe, N. B., Cruzes, D. S., Dybå, T., and Engebretsen, E. "Coaching a global agile virtual team." Proc., 2015 IEEE 10th International Conference on Global Software Engineering, IEEE, 33-37.

Moe, N. B., Dahl, B., Stray, V., Karlsen, L. S., and Schjødt-Osmo, S. "Team Autonomy in Large-Scale Agile." Proc., Proceedings of the 52nd Hawaii International Conference on System Sciences.

Morrison, A., and Rabellotti, R. (2017). "Gradual catch up and enduring leadership in the global wine industry." Research Policy, 46(2), 417-430.

Müller, R., Nikolova, N., Sankaran, S., Hase, S., Zhu, F., Xu, X., Vaagaasar, A., and Drouin, N. (2016). "Leading projects by balancing vertical and horizontal leadershipInternational case studies." PMIRAC Conference, Manageable Cooperation?, India.

Müller, R., Sankaran, S., Drouin, N., Vaagaasar, A. L., Bekker, M. C., and Jain, K. (2018a). "A theory framework for balancing vertical and horizontal leadership in projects." International Journal of Project Management, 36(1), 83-94.

Müller, R., Zhu, F., Sun, X., Wang, L., and Yu, M. (2018b). "The identification of temporary horizontal leaders in projects: The case of China." International Journal of Project Management, 36(1), 95-107.

Ni, G., Cui, Q., Sang, L., Wang, W., and Xia, D. (2018). "Knowledge-Sharing Culture, Project-Team Interaction, and Knowledge-Sharing Performance among Project Members." Journal of Management in Engineering, 34(2).

Niskanen, T., Louhelainen, K., and Hirvonen, M. L. (2014). "Results of the Finnish national survey investigating safety management, collaboration and work environment in the chemical industry." Safety Science, 70, 233-245.

Northouse, P. G. (2015). Leadership: Theory and practice, Sage Publications.

Odusami, K. T. (2002). "Perceptions of construction professionals concerning important skills of effective project leaders." Journal of Management in Engineering, 18(2), 6167.

Odusami, K. T., Iyagba, R. R. O., and Omirin, M. M. (2003). "The relationship between project leadership, team composition and construction project performance in Nigeria." International Journal of Project Management, 21(7), 519-527.

Oladinrin, O. T., and Ho, C. M. F. (2016). "Critical Enablers for Codes of Ethics Implementation in Construction Organizations." Journal of Management in Engineering, 32(1).

Ozorhon, B., Abbott, C., and Aouad, G. (2014). "Integration and leadership as enablers of innovation in construction: Case study." Journal of Management in Engineering, 30(2), 256-263.

Ozorhon, B., and Karahan, U. (2017). "Critical Success Factors of Building Information Modeling Implementation." Journal of Management in Engineering, 33(3).

Papajohn, D., Brinker, C., and El Asmar, M. (2017). "MARS: Metaframework for Assessing Ratings of Sustainability for Buildings and Infrastructure." Journal of Management in Engineering, 33(1).

Paunova, M. (2015). "The emergence of individual and collective leadership in task groups: A matter of achievement and ascription." The Leadership Quarterly, 26(6), 935-957.

Pawson, R., Greenhalgh, T., Harvey, G., and Walshe, K. (2005). "Realist review-a new method of systematic review designed for complex policy interventions." Journal of health services research \& policy, 10(1_suppl), 21-34. 
Pearce, C. L., and Conger, J. A. (2002). Shared Leadership: Reframing the Hows and Whys of Leadership: Reframing the Hows and Whys of Leadership, Sage Publications.

Pearce, C. L., and Sims, H. P. (2002). "Vertical versus shared leadership as predictors of the effectiveness of change management teams: An examination of aversive, directive, transactional, transformational, and empowering leader behaviors." Group dynamics: Theory, research, and practice, 6(2), 172.

Perianes-Rodriguez, A., Waltman, L., and van Eck, N. J. (2016). "Constructing bibliometric networks: A comparison between full and fractional counting." Journal of Informetrics, 10(4), 1178-1195.

Perra, D. B., Sidhu, J. S., and Volberda, H. W. (2017). "How Do Established Firms Produce Breakthrough Innovations? Managerial Identity-Dissemination Discourse and the Creation of Novel Product-Market Solutions." J. Prod. Innovation Manage., 34(4), 509-525.

Perry, S. J., Hunter, E. M., Currall, S. C., and Frauenheim, E. (2017). "Developing Engineering Leaders: An Organized Innovation Approach to Engineering Education." Engineering Management Journal, 29(2), 99-107.

Pesämaa, O., Larsson, J., and Erik Eriksson, P. (2018). "Role of Performance Feedback on Process Performance in Construction Projects: Client and Contractor Perspectives." Journal of Management in Engineering, 34(4).

Pham, N. T., and Swierczek, F. W. (2006). "Facilitators of organizational learning in design." Learning Organization, 13(2), 186-201.

Potter, E. M., Egbelakin, T., Phipps, R., and Balaei, B. (2018). "Emotional intelligence and transformational leadership behaviours of construction project managers." J. Financ. Manag. Prop. Constr., 23(1), 73-89.

Pretorius, S., Steyn, H., and Bond-Barnard, T. J. (2017). "Exploring project-related factors that influence leadership styles and their effect on project performance: A conceptual framework." South Afr. J. Ind. Eng., 28(4), 95-108.

Pries, F., Doree, A., Van Der Veen, B., and Vrijhoef, R. (2004). "The role of leaders' paradigm in construction industry change." Construction Management and Economics, 22(1), 7-10.

Pushkar, S. (2018). "A comparative analysis of gold leadership in energy and environmental design for new construction 2009 certified projects in Finland, Sweden, Turkey, and Spain." Appl. Sci., 8(9).

Quang, H. N., Khuong, M. N., and Le, N. H. (2015). "The effects of leaders' emotional intelligence on employee engagement in Vietnamese Construction Companies-A case of Hoa Binh Corporation." Journal of Economics, Business and Management, 3(8), 746-752.

Rambe, P., and Dzansi, D. Y. (2016). "Informal distributed leadership in technology adoption." Afr. J. Sci. Technol. Innov. Dev., 8(2), 155-165.

Randeree, K., and Chaudhry, A. G. (2012). "Leadership - Style, satisfaction and commitment: An exploration in the United Arab Emirates' construction sector." Engineering, Construction and Architectural Management, 19(1), 61-85.

Randhawa, K., Wilden, R., and Hohberger, J. (2016). "A bibliometric review of open innovation: Setting a research agenda." Journal of Product Innovation Management, 33(6), 750-772.

Rosch, D. M., and Imoukhuede, P. I. (2016). "Improving Bioengineering Student Leadership Identity Via Training and Practice within the Core-Course." Ann Biomed Eng, 44(12), 3606-3618.

Rosenthal, C. S. (1998). "Determinants of collaborative leadership: civic engagement, gender or organizational norms?" Political Research Quarterly, 51(4), 847-868. 
Rowlinson, S., and Jia, Y. A. (2015). "Construction accident causality: An institutional analysis of heat illness incidents on site." Safety Science, 78, 179-189.

Saini, M., Arif, M., and Kulonda, D. J. (2018). "Critical factors for transferring and sharing tacit knowledge within lean and agile construction processes." Construction Innovation, 18(1), 64-89.

Shirazi, B., Langford, D., and Rowlinson, S. (1996). "Organizational structures in the construction industry." Construction Management \& Economics, 14(3), 199-212.

Simmons, D. R., Clegorne, N. A., and Woods-Wells, T. (2017). "Leadership Paradigms in Construction: Critical Review to Inform Research and Practice." Journal of Management in Engineering, 33(4).

Singh, A., and Jampel, G. (2010). "Leadership flexibility space." Journal of Management in Engineering, 26(4), 176-188.

Skinner, B. F. (1938). "The behavior of organisms: an experimental analysis."

Spatz, D. M. (1999). "Leadership in the construction industry." Practice Periodical on Structural Design and Construction, 4(2), 64-68.

Stephens, C. M., and Rosch, D. M. (2015). "Building Leaders: A National Examination of the Leadership Capacities within Engineering Undergraduate Students." International Journal of Engineering Education, 31(4), 986-997.

Styhre, A. (2011). "The overworked site manager: Gendered ideologies in the construction industry." Construction Management and Economics, 29(9), 943-955.

Styhre, A., and Josephson, P. E. (2007). "Coaching the site manager: Effects on learning and managerial practice." Construction Management and Economics, 25(12), 1295-1304.

Sullivan, S. D., Lungeanu, A., Dechurch, L. A., and Contractor, N. S. (2015). "Space, time, and the development of shared leadership networks in multiteam systems." Network Sci., 3(1), 124-155.

Sun, X., Jie, Y., Wang, Y., Xue, G., and Liu, Y. (2016). "Shared leadership improves team novelty: The mechanism and its boundary condition." Front. Psychol., 7(DEC).

Tabassi, A. A., Ramli, M., Bakar, A. H. A., and Pakir, A. H. K. (2014). "Transformational leadership and teamwork improvement: The case of construction firms." Journal of Management Development, 33(10), 1019-1034.

Tabassi, A. A., Roufechaei, K. M., Ramli, M., Bakar, A. H. A., Ismail, R., and Pakir, A. H. K. (2016). "Leadership competences of sustainable construction project managers." $J$. Clean. Prod., 124, 339-349.

Toegel, G., and Jonsen, K. (2016). "Shared Leadership in a Global Context: Challenges of Transferring Control to Team Members." Advances in Global Leadership, Emerald Group Publishing Limited, 151-185.

Toor, S. U. R. (2011). "Differentiating leadership from management: An empirical investigation of leaders and managers." Leadership and Management in Engineering, 11(4), 310-320.

Toor, S. U. R., and Ofori, G. (2008a). "Developing construction professionals of the $21 \mathrm{st}$ century: Renewed vision for leadership." Journal of Professional Issues in Engineering Education and Practice, 134(3), 279-286.

Toor, S. U. R., and Ofori, G. (2008b). "Leadership for future construction industry: Agenda for authentic leadership." International Journal of Project Management, 26(6), 620630.

Toor, S. U. R., and Ofori, G. (2008c). "Taking leadership research into future: A review of empirical studies and new directions for research." Engineering, Construction and Architectural Management, 15(4), 352-371. 
Toor, S. U. R., and Ofori, G. (2009). "Authenticity and its influence on psychological wellbeing and contingent self-esteem of leaders in Singapore construction sector." Construction Management and Economics, 27(3), 299-313.

Toor, S. U. R., and Ofori, G. (2010). "Positive Psychological Capital as a Source of Sustainable Competitive Advantage for Organizations." Journal of Construction Engineering and Management, 136(3), 341-352.

Toor, S. U. R., and Ofori, G. (2011a). "Impact of aspirations and legacies of leaders in the construction industry in Singapore." Leadership and Management in Engineering, 11(1), 29-39.

Toor, S. U. R., and Ofori, G. (2011b). "Women leaders breaking the glass ceiling in Singapore's construction industry." Journal of Professional Issues in Engineering Education and Practice, 137(1), 1-6.

Tranfield, D., Denyer, D., and Smart, P. (2003). "Towards a methodology for developing evidence-informed management knowledge by means of systematic review." British journal of management, 14(3), 207-222.

Tuohy, P. G., and Murphy, G. B. (2015). "Closing the gap in building performance: Learning from BIM benchmark industries." Archit Sci Rev, 58(1), 47-56.

Van Eck, N., and Waltman, L. (2009). "Software survey: VOSviewer, a computer program for bibliometric mapping." Scientometrics, 84(2), 523-538.

Vera, D., and Crossan, M. (2004). "Strategic leadership and organizational learning." Academy of management review, 29(2), 222-240.

Wallhagen, M., and Glaumann, M. (2011). "Design consequences of differences in building assessment tools: A case study." Build Res Inf, 39(1), 16-33.

Wan Muda, W. H. N., Libunao, W. H., Mohd Salleh, K., and Sulaiman, N. L. (2016). "Developing a leadership capability for team leaders in the construction industry: A concept for organizational success." J. Tech. Educ. Train., 8(2), 21-31.

Wang, C. H., and Liu, Y. J. (2012). "Omnidirectional safety culture analysis and discussion for railway industry." Safety Science, 50(5), 1196-1204.

Waziri, A. Y., Ali, K. N., and Aliagha, G. U. (2015). "The influence of transformational leadership style on ICT adoption in the Nigerian construction industry." Asian Soc. Sci., 11(18), 123-133.

Wen Lim, H., Li, N., Fang, D., and Wu, C. (2018). "Impact of Safety Climate on Types of Safety Motivation and Performance: Multigroup Invariance Analysis." Journal of Management in Engineering, 34(3).

Wheatley, M. J. (2010). Leadership and the new science: Discovering order in a chaotic world, Berrett-Koehler Publishers, California, USA.

Williams Jr, Q., Ochsner, M., Marshall, E., Kimmel, L., and Martino, C. (2010). "The impact of a peer-led participatory health and safety training program for Latino day laborers in construction." Journal of Safety Research, 41(3), 253-261.

Woltjer, P. (2015). "Taking over: a new appraisal of the Anglo-American productivity gap and the nature of American economic leadership ca. 1910." Scand. Econ. Hist. Rev., 63(3), 280-301.

Wu, C., Wang, F., Zou, P. X. W., and Fang, D. (2016). "How safety leadership works among owners, contractors and subcontractors in construction projects." International Journal of Project Management, 34(5), 789-805.

Wu, Q., and Cormican, K. (2016). "Shared leadership and team creativity: A social network analysis in engineering design teams." J. Technol. Manage. Innov., 11(2), 1-12.

Wu, W., and Issa, R. R. A. (2014). "BIM execution planning in green building projects: LEED as a use case." Journal of Management in Engineering, 31(1). 
Xavier, R., Komendantova, N., Jarbandhan, V., and Nel, D. (2017). "Participatory governance in the transformation of the South African energy sector: Critical success factors for environmental leadership." J. Clean. Prod., 154, 621-632.

Xu, P., and Shen, Y. (2018). "The Role of Leadership in Agile Software Development." Project Management, 8.

Yan, H., Elzarka, H., Gao, C., Zhang, F., and Tang, W. (2019). "Critical Success Criteria for Programs in China: Construction Companies' Perspectives." Journal of Management in Engineering, 35(1).

Yu, M., Vaagaasar, A. L., Müller, R., Wang, L., and Zhu, F. (2018). "Empowerment: The key to horizontal leadership in projects." International Journal of Project Management, 36(7), 992-1006.

Zhang, B., Le, Y., Xia, B., and Skitmore, M. (2017). "Causes of Business-to-Government Corruption in the Tendering Process in China." Journal of Management in Engineering, 33(2).

Zhang, L., Cao, T., and Wang, Y. (2018a). "The mediation role of leadership styles in integrated project collaboration: An emotional intelligence perspective." International Journal of Project Management, 36(2), 317-330.

Zhang, L., Chen, H., Li, H., Wu, X., and Skibniewski, M. J. (2018b). "Perceiving interactions and dynamics of safety leadership in construction projects." Safety Science, 106, 6678.

Zhang, Y., Zheng, J., and Darko, A. (2018c). "How does transformational leadership promote innovation in construction? The mediating role of innovation climate and the multilevel moderation role of project requirements." Sustainability, 10(5).

Zhou, W. (2014). "When does shared leadership matter in entrepreneurial teams: the role of personality composition." International Entrepreneurship and Management Journal, $1-17$. 